This is the accepted version of a forthcoming article that will be published by Taylor \& Francis in Indonesia and the Malay World: http://www.tandfonline.com/loi/cimw20

Accepted version downloaded from SOAS Research Online: http://eprints.soas.ac.uk/24486/

\title{
'ONE STORY ENDS AND ANOTHER BEGINS’
}

\section{Reading the Syair Tabut of Encik Ali}

\author{
David Lunn and Julia Byl
}

\section{ABSTRACT}

This is the first treatment of a hitherto unknown text, a hybrid lithograph-manuscript from 1864 called the Syair Tabut, or 'Poem of the tomb effigies', by Encik Ali. The only known copy of the Syair, held at Leiden University in the Klinkert collection, and transcribed and translated by Byl, Iskandar, Lunn, and McCallum (2017), describes the Muharram commemorations at Singapore that year. As the poet describes the procession and its consequences, he reveals much about inter-community participation in this ritual event. Significantly, the 1864 Muharram procession ended with an altercation that resulted in the banning of the ritual by the colonial government, and led to two major court cases on native culpability and police corruption. Encik Ali's poem offers an alternative perspective, conditioned by the wide-ranging vocabulary and conventions of Muharram, a vivid description of diverse performances and events, a knowledge of Singapore's urban geography, and the parameters of Malay poetry.

\section{KEYWORDS}

Colonialism; Muharram; paracolonial; Singapore; Syair Tabut

The Taboot festival, which the better informed followers of Mahomet do not observe, is now being celebrated by the lower classes. The procession of the taboots takes place to-night, when as usual, the din of tom-toms \&c., will greet though scarcely gratify the ears of the more quietly disposed portion of the community.

(Straits Times, 18 June 1864, p. 1) ${ }^{1}$

The Syair Tabut of Encik Ali describes the Muharram commemorations in Singapore in 1864. It is a Malay-language account of events that had significant implications for colonial policy and the control of 'native' access to public space in the Straits Settlements, issues which have hitherto been investigated largely through contemporary British colonial journalistic sources and imperfect colonial-era accounts. Reading it against and alongside those colonial narratives complicates and refines our understanding of the trajectories of Muslim and other migrants through South and Southeast Asia, the adaptation of forms of Shi'i religious practice to local conditions and traditions, vernacular cultures of reportage, and the accepted history of the region in the mid 19th century.

\footnotetext{
${ }^{1}$ The Straits Times was, at this point, a weekly paper, published on Saturdays. The summary of the week's news was arranged by day, with this entry filed under 'Wednesday, 15th June'.
} 
This is the accepted version of a forthcoming article that will be published by Taylor \& Francis in Indonesia and the Malay World: http://www.tandfonline.com/loi/cimw20

Accepted version downloaded from SOAS Research Online: http://eprints.soas.ac.uk/24486/

We first approached this text as a potential source on the musical traditions of Southeast Asia. As part of the European Research Council-funded research project 'Musical Transitions to European Colonialism in the Eastern Indian Ocean', the hunt was on for sources, particularly from the 18th and 19th centuries, that might shed light on musical practices on both sides of the Bay of Bengal, and thus provide material for an investigation of the effects that colonialism and colonial epistemologies may have had on these practices and the knowledge systems associated with them in the region: to do, in our oft-bandied about phrase within the project, the history of music before the era of recorded sound. It was during this search that we encountered a fleeting reference to our text - held in the Klinkert collection of the library of Leiden University - at the tail end of Teuku Iskandar's Catalogue of Malay, Minangkabau, and South Sumatran manuscripts in the Netherlands. He records:

1571. Kl. 191 Syair Tabut Scroll, European laid paper, 228x131⁄2 cm.; ca. 53 lines per 50 cm.; lithographed text (fine writing); only 641/2 cm at the end written by hand (bad handwriting); written by Encik Ali at Bangkahulu, assistant (bantuan) to Syaikh Muhammad Ali of Bengali descent; the writing was finished in 1281/1864-65.

A syair on the celebration of the death of Hasan and Husain (grandsons of the Prophet) in Bencoolen; the Bengalis play an important role in this celebration.

(Iskandar 1999: 748)

The Shi'i Muslim festival of Muharram - a public, noisy, and indeed musical event - was a natural object of interest, especially given the transnational connections represented in already known migrations of Muslims and others between South and Southeast Asia and beyond. Bencoolen (Bengkulu), as the location of an early British East India Company factory on the southwest coast of Sumatra, presented an intriguing site for the investigation of this phenomenon, not least in light of the already available scholarship on historical as well as more recent and contemporary Muharram commemorations in that place that emphasises its transnational aspects. ${ }^{2}$

We are indebted to Iskandar - as to all who compile such catalogues, with great labour and dedication - for enabling our encounter with this text, which has not, so far as we can tell, received any substantive scholarly attention to date. ${ }^{3}$ However, we found on closer examination that the events that the author of the Syair Tabut (or perhaps Syair Kudu ${ }^{4}$ ) describes did not take place in Bengkulu, but in Singapore. ${ }^{5}$ The Syair presents the only, to

\footnotetext{
${ }^{2}$ See, for example, Kartomi (1986, 2012), Feener (1999, 2015), and Mason (2016).

${ }^{3}$ The hybrid lithograph-manuscript has occasional markings in blue pencil, frequently alongside the couplets and underlined words that most puzzled us and our colleagues as translators. This suggests some kind of previous scholarly attention, probably from Klinkert himself (presumably for his dictionary). It is perhaps not insignificant that Kl. 191 is omitted from earlier catalogues of manuscripts (e.g. Ali 1985) and the survey of printed materials by Proudfoot (1993), possibly due in part to its mixed lithograph-manuscript format (see below).

${ }^{4}$ The term 'Syair Tabut' does not occur in the text, while towards the end of the syair, the author comes as close as he ever does to giving it a name in his summation 'Syair kudu tamatlah sudah / The poem of the kudu is now finished’ (q. 144a). Thus, Syair Tabut appears to have been assigned by Iskandar, or perhaps Klinkert (though the paper wrap of the scroll has only 'Maleisch Gedicht' [Malay poem] as a notation). Regardless, it serves us well enough, especially as the terms seem more or less interchangeable. See the discussion in our translation note in Byl et al. (2017) on tabut and, particularly kudu.

${ }^{5}$ The mistake is understandable as the poet describes himself as a 'son of Bengkulu' in q. 3a, then quickly follows with a description of Muharram festivities that could easily have had been celebrated in Sumatra. It is not until q. 16b that we find the first Singaporean place name, though even that is ambiguous. Reference is made to groups coming 'from Singapore' in q. 46, while the presence of the 'English Company' seemed particularly strange in post-1824 Sumatra; only in qq. 54 and 56 do definite place names (Kampung Bengkulu and Kampung Gelam) appear. Still, realising the true locale of the poem took us longer than we may wish to admit.
} 
This is the accepted version of a forthcoming article that will be published by Taylor \& Francis in Indonesia and the Malay World: http://www.tandfonline.com/loi/cimw20

Accepted version downloaded from SOAS Research Online: http://eprints.soas.ac.uk/24486/

our knowledge, vernacular account of the Muharram commemorations of 1864 in that city. The violent disturbances that year had significant consequences; a major trial was held of supposed ringleaders of the Red Flag 'secret society' in the 'Great Conspiracy Case' of 1865, and Muharram processions were banned in Singapore from the following year on. ${ }^{6}$ This no doubt gratified European residents of the city, who viewed the commemorations as little more than a threat to public order, decency, and decorum, as well as an incomprehensible and ill-appreciated sonic intrusion into their day-to-day lives. ${ }^{7}$ Yet it had an enduring impact on the Muslims of Singapore and the space afforded to devotional expression. Encik Ali's Syair thus offers a qualitatively different narrative to that encountered in the colonial archive: by turn vibrant, devotional, celebratory, witty, colourful, sincere and nuanced in ways that the official, journalistic, and memoir accounts of Europeans, marred by their less than perfect understandings of the realities of quotidian subaltern existence, could never hope to achieve. Moreover, the Syair presents an assessment of where culpability should lie for the violence that erupted that year that is strikingly different from that revealed in European journalism or colonial courts. It represents a stark indictment of policing practices in the colony: practices which would come under close scrutiny in the subsequent 'Police Conspiracy Case' of 1866, the transcripts of which seem to support many of the claims alleged first in the Syair.

The Syair provides important details on the so-called secret societies of the Red and White Flags - a persistent bugbear for the European rulers of the Straits Settlements, and linked in their imagination to Chinese Triad societies. Furthermore, as an object of historical record, it testifies to the heterogeneity that obtained in Southeast Asian commemorations of Muharram in the 19th century, including a cast of participants spanning the length and breadth of colonial Malaya and the archipelago, and incorporating migrants from South India, north and east India, Thailand, and Burma. Yet it is also a performative text (and, we infer from the text itself, one that may well have been performed), ${ }^{8}$ referencing the types of songs, performance genres, and musical ensembles involved in the annual ritual remembrance of the martyrdom of Hussain and his companions at Karbala - somewhat richer and more varied than the disdainful 'din of tom-toms' one finds in the Straits Times. It is something of a linguistic minefield, which has stretched our abilities as scholars of South and Southeast Asia to their limits as we attempted to trace reliably the meanings and etymologies of words and expressions that are occasionally bewildering in their diverse origins, bearing as they do the imprint of generations of migration, colonial rule, and port-city cosmopolitanism. And finally, the frequently qualified, yet far from neutral account of Mr Ali - our self-effacing 'fakir' and the otherwise largely unknowable author of the text ${ }^{9}$ - has implications for our understanding of authorship, attribution, and historical veracity in the context of accounts by 19th-century colonial subjects, and the intersection of such accounts with processes of public justice and state retribution.

We attempt to demonstrate the significance of the Syair Tabut in all of these areas, and analyse historical accounts in the light of its literary insights, beginning with the form and

\footnotetext{
${ }^{6}$ Similar steps were taken slightly later in other parts of the Straits Settlements, notably Penang. See below.

${ }^{7}$ See Jenny McCallum 2017b (this issue) for an analysis of 'noise' in colonial Singapore.

${ }^{8}$ See the repeated invocations in the Syair Tabut to hear or listen (dengarkan): indeed, it is the first word of the poem (q. 1a-b) - 'Dengarkan tuan suatu kisah / Bulan muharram empunya termasa' ('Hear, sir, a story about / A festival of the month of Muharram'). We should not over-interpret this, however, as such an opening is a common enough convention.

${ }^{9}$ As Ulrich Kratz has observed with reference to the Malay manuscript tradition (1981: 233), 'it should be pointed out ... that most Malay texts are anonymous, and that we do not know who is usually hiding behind phrases like fakir, yang empunya cetera, and sahibu'l-hikayat' - as such, Encik Ali's self-presentation (qq. 2-3), sparse as it is, gives us more information than we might otherwise hope for.
} 
This is the accepted version of a forthcoming article that will be published by Taylor \& Francis in Indonesia and the Malay World: http://www.tandfonline.com/loi/cimw20

Accepted version downloaded from SOAS Research Online: http://eprints.soas.ac.uk/24486/

origin of the physical copy, some observations on the language of the syair, and an outline of the narrative, before moving to discuss its historical and sociological implications.

Simultaneously, we hope not to drown this virtuosic and entertaining text in a deluge of scholarly prose; its literary and narrative merits should be appreciated for themselves, despite our inevitable obscuring of them both here and in translation. We believe that the text is of profound relevance to scholars in a variety of disciplines - linguists, philologists, literary scholars, and historians, as well as musicologists. We make reference to our accompanying transcription and translation of the text (prepared with our colleagues) by quatrain number, ${ }^{10}$ and, ultimately, invoke its author in absolution:

Jika ghalat tuan mengapakan

Aturan yang janggal tuan sajakkan
If there are mistakes, sir, do something about them If the rhymes are awkward, sir, improve them. ${ }^{11}$

\section{The form and origins of the text}

Ali's Syair is an account of contemporary events. The colophon in quatrain 145b gives the date of composition as 'Seribu dua ratus lapan puluh satu' ('One thousand two hundred eighty-one' or 1281 AH/1864-65 AD, and 10 Muharram that year equates to 15 June 1864 . The lithographed scroll was almost certainly printed at the Singapore Mission Press, run by the Reverend Benjamin Keasberry. ${ }^{12}$ The scroll is formed of seven pieces of paper, joined together after lines 28 (q. 14), 72 (q. 36), 118 (q. 59), 162 (q. 81), 208 (q. 104), and 254 (q. 127), with 44 or 46 lines of Jawi script on each sheet but the first and last. The beginning of the Syair is decorated with an intricate floral pattern, clearly marking it out as a product of either Keasberry himself or, perhaps more likely, one of his students (see Figure 1a). ${ }^{13}$ Its form is rare indeed, ${ }^{14}$ though very similar in its physical properties to the copy of Munsyi Abdullah's Syair Kampung Gelam Terbakar also held at Leiden University (Figure 1c): the floral decorative header is nearly identical, combined with the matching layout of the text to suggest that both were from the same press. The similarities do not end there. If the tentative dating of the copy of Abdullah's syair to 1847 by Proudfoot (1993: 298) is accurate, and Amin Sweeney has strongly suggested that it is, ${ }^{15}$ we can see in both that case and ours a use of the syair form and the lithographed (scroll) copy to comment on recent events of civic importance. Proudfoot (1987: 1-2) has remarked of the late 19th-century publishing context of Singapore that 'Books published [there] were not generally so topical as the periodicals':

\footnotetext{
${ }^{10}$ The Syair Tabut has 146 quatrains, each with a recurring rhyme, which is the basic structure of the syair form. Where necessary, we refer to specific lines of each quatrain by a, b, c, or d.

${ }^{11}$ Syair Tabut, q. 10c-d. While we translate 'tuan' as 'sir', it is more properly a gender-neutral pronoun in this 19th-century context. That said, Ali also addresses his audience as 'encik-encik' in q. 57 a.

${ }^{12}$ Many of the insights into the origins of the scroll were provided by Annabel Teh Gallop (personal communication, October 2016) to whom we are exceptionally grateful.

${ }^{13}$ For brief notes on Keasberry and the Singapore Mission Press, see Proudfoot (1995: 218-19). As he states, 'Keasberry used the profits generated by his press to support Malay mission schools, while at the same time training schoolboys in the craft of printing.' See too his description of Keasberry and the Mission Press as typifying the 'second phase' of lithographic printing in the region (Proudfoot 1998: 122-7).

${ }^{14}$ See Iskandar's observations in his Catalogue (1999: xi): 'There are also a number of MSS written on scrolls, usually pieces of paper pasted together. Works on scrolls are mostly genealogical trees, only sporadically literary texts', noting the Syair Tabut as an exception to this general rule.

${ }^{15}$ See Sweeney (2006: 59-60) for a discussion of the Leiden copy (O 870 G 89). See too his photographs of the 325cm-long scroll, stored in a folded concertina manner (ibid.: 390-1). If, as Sweeney observes, Abdullah was sending copies of his syair to Paris at the start of August 1847, it had been composed, printed, and was circulating internationally within a few months of the events it described (the fire at Kampung Gelam occurred on 12 February).
} 
This is the accepted version of a forthcoming article that will be published by Taylor \& Francis in Indonesia and the Malay World: http://www.tandfonline.com/loi/cimw20

Accepted version downloaded from SOAS Research Online: http://eprints.soas.ac.uk/24486/

the presence of the Syair Tabut in the 1860s invites us to consider how the syair form occupied an intermediate space, as a literary work being used for commentary and reportage in an immediate sense in the context of an 'active publishing industry that was keenly commercial'. We cannot infer anything about the extent of the circulation of the Syair from the fact that there appears to be only one extant copy. Still, the Syair Tabut conforms to what John McGlynn, writing of the Syair Lampung Karam, has called a 'syair kewartawanan' or 'journalism poem', after Sri Wulan Rudjiati Mulyadi (McGlynn 2014: xxiii); in another formulation, Ali's is an example of 'the syair style [which] was chosen to produce ... the journalism of the manuscript age', enduring into the age of the lithograph (Proudfoot and Hooker 1996: 67).

In another similarity to Abdullah's account of the Kampung Gelam fire, our Syair is lithographed in what Annabel Teh Gallop (2015: 36) has termed the '19th-century Straits scribal hand'; to add to her observations of that script as 'often highly proficient and disciplined', we may note that the bulk of the Syair Tabut that is lithographed is clear, elegant, and relatively easy to read. The same cannot be said of the end of the Syair: the seventh and final piece of paper (q. 128 on), joined with the rest of the scroll, is written in an exceedingly poor hand, presenting us with major - at some points, insurmountable obstacles to our transcription of the text (Figure 1b). We cannot offer any explanation as to the final form of this text - a hybrid lithograph-manuscript - and are unaware of any other copies with which we might compare it. ${ }^{16}$ Much remains to be considered regarding the place of this Syair in the literary economy of mid 19th-century Singapore, not least the implications of such physical copies for the printing business there. Encik Ali remains a largely unknown figure, and research into his background is one of many desiderata.

\footnotetext{
${ }^{16}$ It could have been, for example, a printer's draft, incomplete at the end, or a final version from which the final piece of paper and thus concluding section became detached. Ulrich Kratz (1981: 236) has remarked ironically on the 'fortuitous interest of a European' that accounts oft-times for the availability of manuscripts in European collections, and notes both that their acquisition per force meant 'taking them out of circulation', and the paucity of information on the motivations and opportunities to collect. Related to this, the upper edge of the Syair Tabut scroll carries the notation, in a fine-lined European hand, 'Price 75 cents'. We are unable to speculate further what this may indicate about its circulation - either as a generically/mass-printed text or an individual item - or its entry into Klinkert's collection.
} 


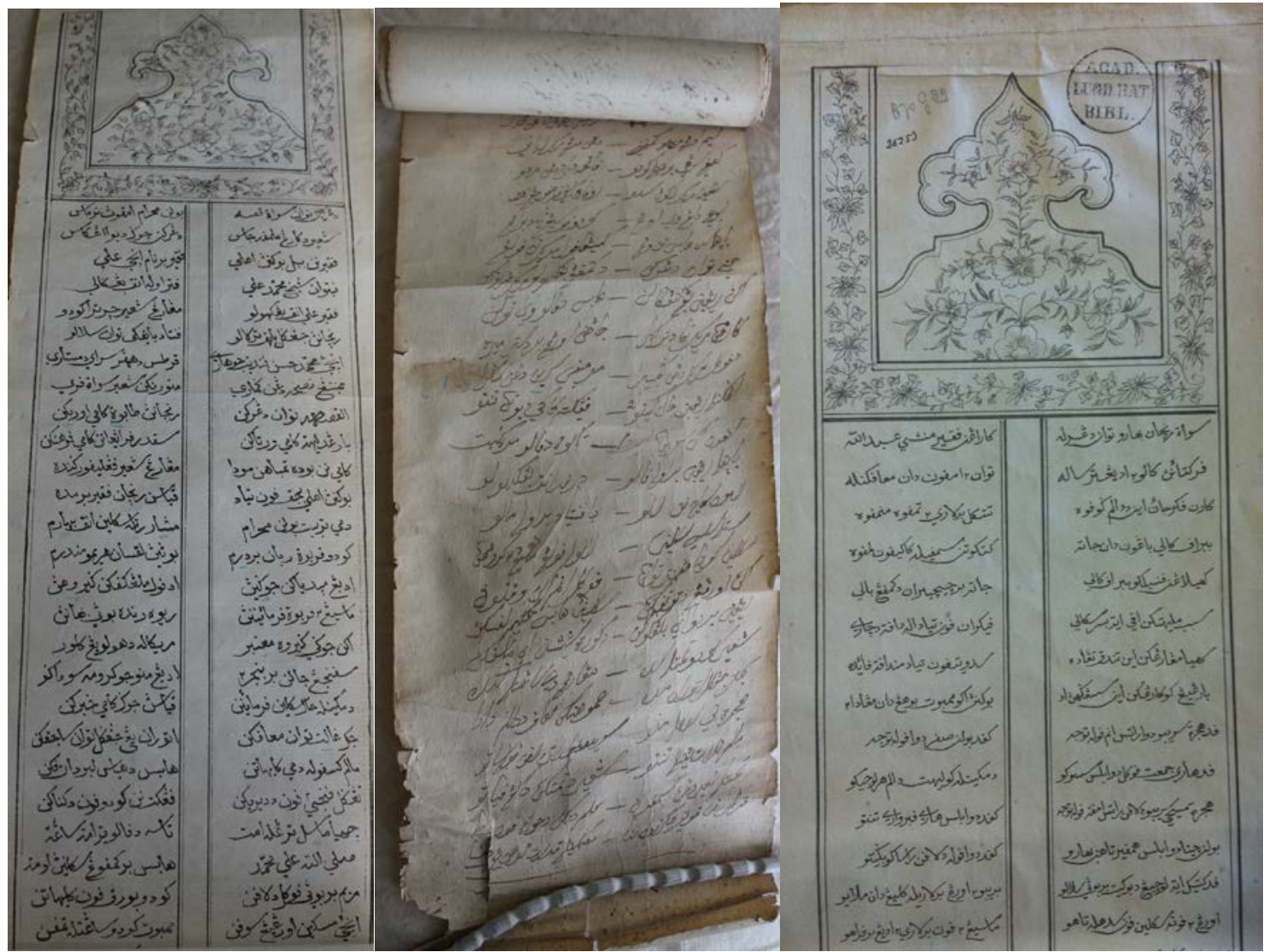

Figure 1 Left to right: 1a and 1b Opening and final lines of Syair Tabut; 1c Opening lines of Syair Kampung Gelam Terbakar. Courtesy of University Library Leiden, ref. KL 191 (a and b); O 870 G 89 (c).

\section{The languages of the Syair}

Some of the vocabulary used in Syair Tabut was particularly difficult for us to understand and translate. We view this as indicative of two things: firstly, the multilingual milieu of late 19th-century Singapore, and the multiple strands of linguistic transmission that that situation entailed; and secondly, the linguistic and literary versatility of the author himself. What to a contemporary reader is an etymological puzzle of some complexity was surely, to the author, an opportunity to display his erudition and creativity and, quite possibly, a source of pleasure to contemporaneous audiences.

A couple of examples merit particular attention. Two of the most significant words in the syair are 'jīgì' (جوكي) and 'gìrūh' (كيروه). Neither of these is known to contemporary Malay speakers, nor are they to be found in current or historical dictionaries of the language, whether roman or Jawi. ${ }^{17}$ A degree of imaginative re-spelling, however, reveals them to be Persian terms, also used in Urdu/Hindustani - 'jaukh/jauq' (جوق/جوخ) and 'gurōh' (كروه) and synonyms, both meaning a troop, body, company, or band of men (Platts 1884: 397, 906; Steingass 1963: 378, 1085). If the military associations of the terms weren't enough, the attestation of the latter in Ja'far Sharif (1975) strongly suggests the transmission of the vocabulary via Indian sepoys, particularly Muslims, in the mixed regiments from the Bengal

\footnotetext{
${ }^{17}$ At least, not in the sense used in the Syair Tabut. Jūgī of course exists as a variant of 'yogi'.
} 
This is the accepted version of a forthcoming article that will be published by Taylor \& Francis in Indonesia and the Malay World: http://www.tandfonline.com/loi/cimw20

Accepted version downloaded from SOAS Research Online: http://eprints.soas.ac.uk/24486/

and Madras Native Infantry. ${ }^{18}$ They are used apparently interchangeably to refer to the groups which accompanied the various effigies in the procession. Indeed, the suggestion to look elsewhere for the etymology of these terms comes from the author himself: 'Adalah pula suatu pasukan / ... / Bahasa Benggali giruh dinamakan' ('A battalion was there as well / ... / It was called a giruh in Bengali'; q. 17a, d). ${ }^{19}$ The phonetic shift involved in their entry into this Syair is substantial, but not inexplicable.

The term ringin has presented a particularly intractable problem. The word itself may refer to the banyan tree (more commonly, beringin), a symbol of authority in the Malay world. This meaning was not immediately satisfactory to us, but our search for other possible etymologies has proven inconclusive. The word in Ali's usage seems to refer to either an individual, associated particularly with the Red Flag group from Kampung Dhoby or Dhoby Ghaut (that is, the river bank or ghät where the dhobi/laundrymen laboured), or, alternatively, a group of dhobi with no specific geographical connotations. It may indicate a status within a Kling/Indian secret society, thus conforming to the leadership associations of the banyan. It may also refer to a group, as the use of the term in a contemporary newspaper seems to suggest; in its account of the proceedings of the 'Great Conspiracy Case', the Straits Times reported the testimony of Hussainsah [sic], who stated 'that he became a member of the "Ringin” of the red flag Society by compulsion in July 1864' (Straits Times, 16 October 1865, p. 2), without providing any kind of gloss or elaboration on the term. While we certainly cannot determine a Chinese etymology, ${ }^{20}$ it is possible that it is a Malay word being used to indicate an equivalent Chinese term, perhaps denoting status within a society: so, for instance, 'the Master (Sinse ${ }^{n} /$ Xiansheng [先生], a term that the British often translated as “secretary”)' (DeBernardi 2004: 86), or linked to what Jean DeBernardi attests as the term for 'the fighting men ... of the sworn brotherhoods', samseng (ibid.: 78). ${ }^{21}$

Ali's Sumatran background finds some expression in certain Minangkabau inflections throughout his poem. The most obvious is the frequent use of the particle nan, in place of the standard Malay yang (see e.g. q. 19d), though this in itself is not uncommon in syair. The use of matagi in q. 38b is similarly suggestive, as is the recent attribution of Minangkabau, that is, Sumatran origins of the entry into Indonesian of the Indian word tasa (see note to q. 12b). Arabic is used in specifically Islamic invocations - for instance, in q. 12c 'Salli Allah ali Muhammad / Bless Allah and the household of Muhammad!' - as well as the unusual use of the definite article in 'Al-kisah / the story' in quatrains 5 and 85, perhaps claiming a certain rhetorical authority for his account. Our transcription and translation of the syair (Byl et al. 2017) notes the Persian/Hindustani origins of bibadal and speculates on the possible Tamil origins of kudu as a specifically Singaporean term for tabut, according to Wilkinson (1903: 506). Other Tamil-derived terms are remarked on in the endnotes to the Syair (Byl et al. 2017). Meanwhile, 'Ratu Ranjuna / Prince Arjuna' in q. 121c not only draws on the aesthetic

\footnotetext{
${ }^{18}$ Sharif (1975: 169-70) describes the Muharram commemorations and the various people involved in South India, observing that 'Faqīrs ... form a band (guroh) with various ranks and titles, under a director (murshid) or a leader of the troop (sarguroh), whom all agree to obey.'

${ }^{19}$ See our note to q. 17 in the transcription (Byl et al. 2017); 'Bahasa Benggali' does not necessarily refer to Bengali per se, but much more likely a general Sepoy Hindustani.

${ }^{20}$ We had even considered that something involving the Chinese character 人 rén ('people') might be possible.

${ }^{21}$ The latter term does not occur in Wilkinson, but features in Stevens and Schmidgall-Tellings (2010: 869, s.v. samséng) as of Chinese derivation, with the sense 'hooligan, rowdy person'. DeBernardi classes it as 'slang ... Southern Min, possibly borrowed from Cantonese’ (2006: 351). Ward and Stirling supplied extensive examples of what DeBernardi characterises as 'secret slang antilanguages' in use in Chinese secret societies; whether or not ringin is being used in a similar way in the context of South Indian societies remains unclear but possible (Ward and Stirling 1925, I: 129-31).
} 
This is the accepted version of a forthcoming article that will be published by Taylor \& Francis in Indonesia and the Malay World: http://www.tandfonline.com/loi/cimw20

Accepted version downloaded from SOAS Research Online: http://eprints.soas.ac.uk/24486/

world of wayang kulit and the mythological associations of the Mahabharata, but does so through a distinctively Javanese linguistic inflection (see too 'Raden Kalu' in the subsequent quatrain).

As to Ali's linguistic versatility, we are reminded of of the declaration by R.J. Wilkinson (1907: 1-2), that 'every Malay author is an amateur philologist - a "lover of words" in the most literal sense'. Wilkinson (1907: 5) also notes that 'the pioneers of modern Malay literature ... would have commended the man who spoke such excellent Malay that no one could follow him, and the man who enriched his vocabulary with treasures from other languages such as Arabic, Persian, Hindustani, English and Chinese'. Such a jaded perspective might mitigate against a more positive reading of Ali's flair, predicated on a certain minimum level of comprehensibility and the jouissance that would accompany reading or hearing such a text. Indeed, the brief discussion of examples thus far suggests an approach closer to what Maria Lauret (2014: 2) terms 'wanderwords', able to 'perform wonders of poetic signification as well as cultural critique'. As it stands, making a definitive judgment regarding the aesthetic merits contemporary audiences may have found in the Syair is impossible. Our own difficulties - and moments of great pleasure - as translators cannot be taken as indicative of experiences over 150 years ago.

\title{
Syair Tabut: a precis, and a note on geography
}

\author{
[Image available in published version]
}

Figure 2 'View of a "Tabut" (shrine) procession by Shia followers'. Source: E. Schlitter, Erinnerungen an Singapore 1858. Courtesy of the National Museum of Singapore, National Heritage Board, accession no. HP0064-S

The Syair begins with a standard set of invocations, imploring the listener to hear a 'story about / a festival of the month of Muharram /... written as a service' (q. 1a-c). Ali introduces himself as a man of Bengkulu descent (anak Bangkahulu - q. 3) and now assistant to a Sheikh Muhammad Ali (of Bengali descent). The narrative proper commences in quatrain 7, when the people of Baharam (anak Baharam; see note to the quatrain) come together on the first day of Muharram to begin constructing their tabut, kudu, or tomb effigy. By quatrain 11, the action has already shifted to the focus of the Syair - the events of 10 Muharram, or Ashura, when the effigies representing the tombs of Hasan and Hussain, and the buruq (q. 13 b, the kudu borak or 'buraq effigy'), would be paraded through the settlement. We encounter the tabut group from Dhoby Ghaut with their red flags, and another group, the 'fakirs of Halqah al-Mannan', with white flags (qq. 16-17); the term ringin, likely referring to a group, party, or gang, is clearly associated with the Red Flags (qq. 19-20). From quatrain 22 on, Ali gives us a detailed account of the various groups (jugi, giruh, or angkatan) involved in the procession of tabut - the groups from Baharam, Dhobies (perhaps from Dhoby Ghaut), and Penang, a group of 'Klings' (South Indians), another from (possibly Kampung) Bengkulu, with interspersed participants of Burmese, 'Bengali' (see below on the ambiguity of this term), Siamese, and Peranakan origin. Many of these are organised in 'boats' (sampan, lancang; at one point pusta), perhaps akin to the English floats of celebratory parades (given his metaphorical description of one of these as 'seaworthy' (q. 28b), we have retained 'boat' in the translation) - some were certainly borne by participants, 
This is the accepted version of a forthcoming article that will be published by Taylor \& Francis in Indonesia and the Malay World: http://www.tandfonline.com/loi/cimw20

Accepted version downloaded from SOAS Research Online: http://eprints.soas.ac.uk/24486/

but others were likely mounted on carts (see the references in qq. 44 and 104 to kereta, and the late 19th-century photograph of one such in Figure 3). In addition to the descriptions of clothing, performances and music, there are foreshadowings of violence and rivalry to come, e.g. quatrain 44, or in his disparaging of the kudu of the ringin/Dhoby Ghaut party as less splendid than the others (q. 45), but the overall tenor is of an exuberant, participatory event.

[Image available in published version]

Figure 3 'Shia Muslim procession to celebrate Muharram', postcard, late 19th century. Courtesy of the National Museum of Singapore, National Heritage Board, accession no. XXXX-00423.

The tone changes briefly but significantly around quatrain 52, with the intrusion of the Kompeni Inggeris or English Company - an anachronism, but though East India Company control of British India, of which the Straits Settlements were a part until 1867, had ended in 1858, use of the term persisted to refer to both British and Dutch colonial authorities - and the 'inspector' (merinyu) is first mentioned in quatrain 19. Ali directly attributes a shift in the mood of the crowd in part to the presence of colonial officers: 'Kompeni juga yang sangat terasa' / 'The Company's presence was very much felt' (q. 53c). While Ali dwells briefly on animosity between residents of Kampung Bengkulu and Dhoby Ghaut, as the procession moves towards Kampung Gelam (Glam), the narrative swiftly returns to a description of the crowds and the build-up to the procession of the effigies (qq. 57 on).

The police inspector returns in quatrain 77, intervening in the conduct of the Muharram procession as it moves through Kampung Bengkulu. The 'White flags' and 'Red flags' of quatrain 78 attest again to the competitive aspect of the events taking place, and rivalry between these groups - clearly linked to distinct Indian (Tamil Muslim) communities and 'secret societies' with specific local areas of influence and association - and that distinction dominates much of the subsequent narrative (see below). A violent disturbance intrudes at quatrain 93, when stones are thrown at the inspector; Ali suggests in quatrain 95 that the officer ordered some kind of inter-society retribution in retaliation for this indignity. Police intervention continues through the remainder of the narrative, with bribes taken (q. 98d), 'around a hundred' members of the White Flag society arrested (q.97), the procession of kudu stopped and restarted, and a general sense of disturbance and destruction. At this point the geography of the narrative is somewhat opaque: something occurred 'in Singapore', seemingly distinct from Teluk Ayer, which, however, our narrator is at pains to distance himself from, telling us several times that, for instance, he 'did not go to Singapore' and is thus 'afraid of fabrication' (q. 116a-b). ${ }^{22}$

By quatrain 121, things have calmed down, and by 4 o'clock a tone of reverence returns as the effigies are brought to the river for immersion (q. 124), and the 'believers' or Muslim participants are joking amiably and 'bathed to avoid any misfortune' (q. 127d) at the conclusion of the ceremonies. The aftermath - the ringin left behind in Kampung Bengkulu

\footnotetext{
${ }^{22}$ The notion of 'going to Singapore' merits clarification. It seems that for Ali, as for others, Singapore referred to the European area north of the Singapore river, the old civic centre of the settlement, and thus what took place in the predominantly non-European areas south of the river did not qualify as being 'in' Singapore. This geographical imaginaire is corroborated in European accounts: see W.H.M. Read (1901: 101) describing a wholly different event with 'a band of Chinese marching along the Bukit Timah Road, with the intention of forcing their way to Singapore'.
} 
This is the accepted version of a forthcoming article that will be published by Taylor \& Francis in Indonesia and the Malay World: http://www.tandfonline.com/loi/cimw20

Accepted version downloaded from SOAS Research Online: $\underline{\text { http://eprints.soas.ac.uk/24486/ }}$

and beaten (q. 138), others arrested (and 'all ... released by the judge', q. 143b) - brings us to a consideration of the other ways in which the events Ali describes entered the colonial archive. We must read it in the context of public debates over the regulation of space, societies, and processions in 19th-century Singapore, and consider the specificities of Ali's account when put alongside these other, more widely utilised but similarly incomplete narratives. 
This is the accepted version of a forthcoming article that will be published by Taylor \& Francis in Indonesia and the Malay World: http://www.tandfonline.com/loi/cimw20

Accepted version downloaded from SOAS Research Online: $\underline{\text { http://eprints.soas.ac.uk/24486/ }}$

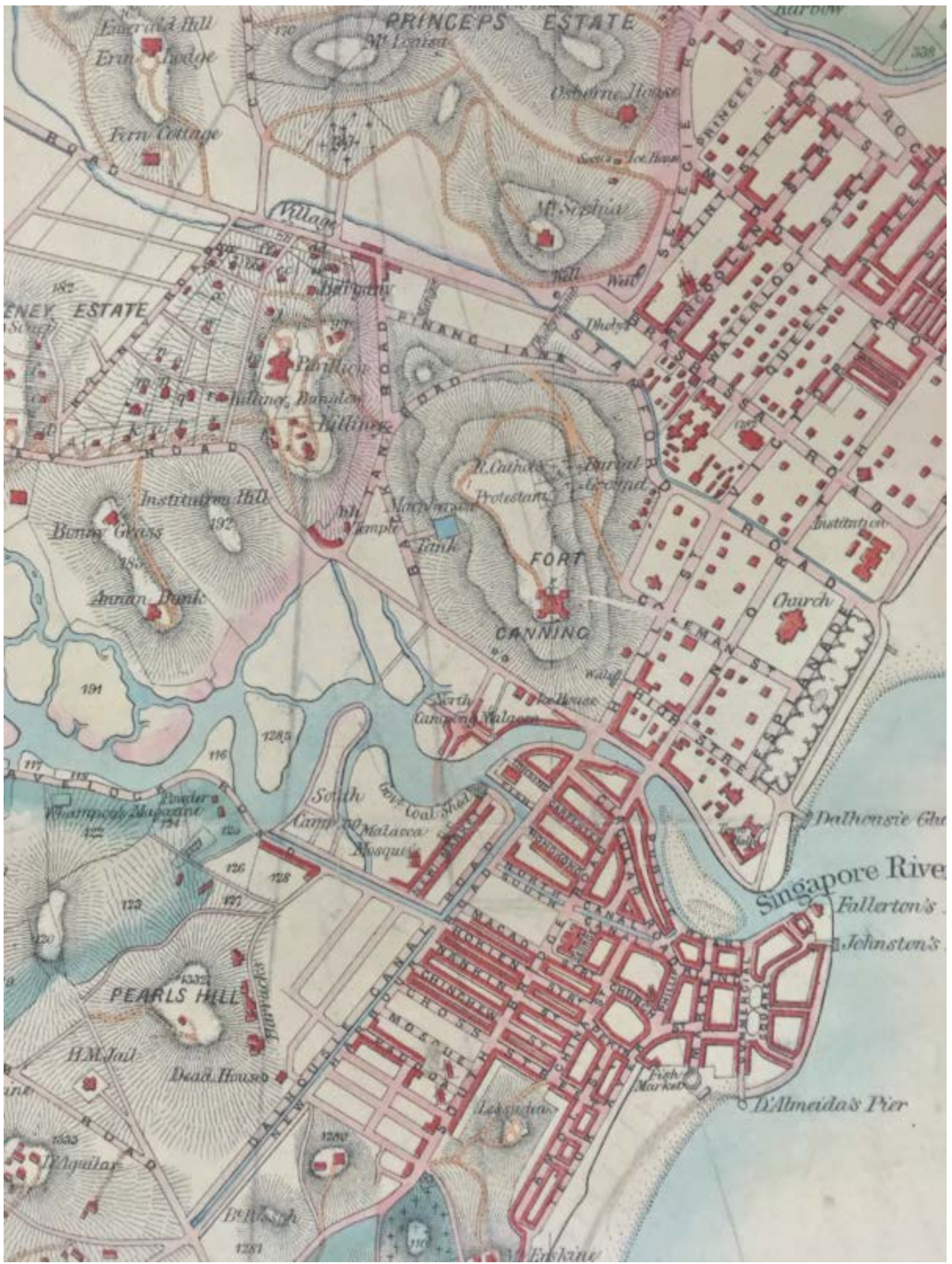

Figure 4 Detail of a map of Singapore, marked Singapore Residency, Col. Orfeur Cavenagh, Governor, J.

Monbiot, Surveyor General. Printed and published by Smith, Elder \& Co., London. n.d. (c. 1865: Cavenagh was Governor 1859-67). Source: The National Archives UK ref. WO 78/2256.

The geography of Singapore as represented in the Syair is not always explicit or entirely clear. This would be less of a problem if regions of the settlement - streets and kampung did not carry ethnic or community associations, but they do: in the context of Singapore's 
This is the accepted version of a forthcoming article that will be published by Taylor \& Francis in Indonesia and the Malay World: http://www.tandfonline.com/loi/cimw20

Accepted version downloaded from SOAS Research Online: http://eprints.soas.ac.uk/24486/

evolution as a semi-planned settlement, and in the Syair itself. Both of these issues are present in Ali's references to the orang dubi. As we note in the translation (Byl et al. 2017: n. q. 16b) this could indeed refer simply to 'laundry people'; however, it seems to refer more specifically to residents of an area, particularly given the geographical affinities of the various Flag societies, so we interpret it as residents of Dhoby Ghaut. In Lieutenant Philip Jackson's 1822 plan (also known as the Raffles Town Plan), no reference is made to such an area beyond 'Dobies Village', hard by the Rochor River and close to modern-day Little India. The utility of this plan is limited: H.F. Pearson (1953: 200) argued quite conclusively that it was an 'idealistic project which did not fully materialise'. Moreover, much can change in 42 years. J.T. Thomson's 1846 plan is more reliable, and while it has no 'Dobies Village', it explicitly marks 'Doby Ghaut Rd.' Road layouts have changed, but that short road began north of 'Government Hill' (Fort Canning) and ran northeast from 'Pinang Road' toward Mount Sophia and Selegie Road before turning southeast into Bras Basah Road, all of which remain today. This marked the southeast boundary of what is today Dhoby Ghaut - perhaps one mile southwest of the 'Dobies Village' in the Jackson plan. The road and the area are clearly marked on a map prepared under J. Moniot c.1865 (see Figure 4), which also usefully shows the European street names south of the Singapore river (i.e. modern-day Chinatown and surrounds) where the bulk of the events described in the Syair took place. ${ }^{23}$

By the 1890s, H.T. Haughton felt it a useful service to list the various names - besides their 'official' ones - that streets in the settlement were known by. So, he suggests that Dhoby Ghaut was known as ‘வண்ணுன் தெருவு'/‘Vannan Therevu' or 'Street of the dhobies' in Tamil (that is, using the Tamil caste name of Vannar for dhobi), while 'Dhoby Kampam'/‘டோபி கம்பம்’ or, in Malay, Kampung Dhobi, referred to Queen Street (Haughton 1891: 63-4). His article is a mine of other intriguing examples of parallel naming conventions. Multiple names for streets or areas is one thing, but certainty around the ethnic mix of specific locales is hard to achieve, and is more fraught when we consider Ali's use of toponyms that may on occasion be ethnonyms as well or instead. For instance, Kampung Bengkulu refers to the area around Bencoolen Street, close to Dhoby Ghaut. The use of the 'kampung' in contradistinction to street names creates a certain amount of spatial ambiguity, as well as pointing to an alternative system of knowing and naming urban space (some European maps chose to mark the various kampung: an 1878 map has them arching over street names, while another from 1852 - in consequence of scale, perhaps - marks them almost as an alternative to streets). ${ }^{24}$ It is the reference style preferred by Ali, with clear references to kampungs Bengkulu/Bencoolen, Susu (i.e. Cross Street), and Glam. The precise ethnic makeup of the area, and thus the associations of the term in the Syair, is not wholly clear at this stage. Savage and Yeoh (2013: 52, 33) suggest it was originally settled by 'Bencoolen Malays' or 'Muslims from Bencoolen', but both the imprecision of kampung boundaries and the large number of Indian-origin people in the vicinity seem noteworthy. Certainly, these geographical terms retain an importance for Ali, as the processions move through and around the areas of the city, including the European quarter. Indeed, spatial ambiguity compounds racial and affiliative ambiguity, an effect intensified in the case of the distant reader.

\section{Secret societies, police, and Muharram in the streets}

\footnotetext{
${ }^{23}$ See the description of processional routes in $\mathrm{n}$. 28 below.

${ }^{24}$ The National Archives, UK, WO 78/2425 and CO 700/STRAITSSETTLEMENTS5 respectively. The latter also marks ‘K[ampung] Dobie’ as equivalent to Queen Street, nicely supporting Haughton’s later work already quoted.
} 
This is the accepted version of a forthcoming article that will be published by Taylor \& Francis in Indonesia and the Malay World: http://www.tandfonline.com/loi/cimw20

Accepted version downloaded from SOAS Research Online: $\underline{\text { http://eprints.soas.ac.uk/24486/ }}$

Last night, a row on a large scale between two rival Taboot processions very nearly took place in town, which it is supposed would have led to a serious breach of the peace, but for the prompt steps taken by the Police in the matter. But, as it was, there have been some disturbance [sic], during which missiles of every description in the shape of bricks, bottles, \&c., were thrown about inflicting minor wounds on the mob.

(Straits Times, 18 June 1864, p. 1) ${ }^{25}$

The Moharram, which, as a Mahomedan feast, would in any case lead to quarrels, became most dangerous when the Red and White Flags have yearly made it the occasion for fighting, stone-throwing, \&c., and in consequence permission for the procession has been refused.

(R.W. Maxwell, 'Report on the Police Force for the year 1877’, Straits Times, 6 July 1878, p. 2)

The Syair Tabut makes a significant contribution to the historiography of Singapore and the Straits Settlements more generally in the late 19th century, notably around questions of the regulation of the various 'native' populations, their intermingling, and their access to and use of public spaces for particularly religious festivals. Additionally, the Syair allows us to read the account of the later Police Conspiracy Case trial - in which several officers, both European and 'native', stood accused of bribery and taking sides in the inter-society conflict - in a new light, and take seriously Ali’s largely first-hand, insider testimony.

Torsten Tschacher (2009: 59) has drawn our attention to how Muharram processions and other, particularly 'popular' Islamic practices, 'were shared among South Indian and Southeast Asian Muslims, creating connected trajectories of religious practice'. This is borne out by the Syair's description of the events in Singapore, though as DeBernardi notes of contemporaneous Muharram processions in Penang, the scale of participation was wide, incorporating all ethnic communities in that place (with the glaring exception of the British):

In 1859 and 1862 the registered participants included teams of Bengali, Malay, Hindu, Tamil, Chinese, Burmese, and Portuguese (no doubt Eurasian) dancers. The Chinese contributed two singha or lion dance teams of fifteen to twenty performers.

(DeBernardi 2006: 20) ${ }^{26}$

The multi-ethnic composition of these commemorations in Penang is largely replicated in the Syair's account of Singapore, though the latter makes no mention of lions as either figures or dance troupes, ${ }^{27}$ nor is the Chinese community prominent - in fact, the Syair makes no explicit reference to Chinese participation at all. Thus, while newspapers at the time focused on the Indian, or Kling, aspect of the Muharram, it seems clear that the processions drew in a diverse cast of participants from South India, Bengal, Burma, Penang, Pulau Bawean, Sumatra, and Thailand, with a racial mix including Peranakan. We have no explicit evidence in the Syair that non-Muslims were participants in the processions, and particularly the masquerades, though we might assume that there were. As we explore in the next section, the carnivalesque atmosphere - that so closely resembles aspects of Ja'far Sharif's near contemporary descriptions of Muharram in India - was the forum in which diverse communities brought their performance traditions together, and was thus not only 'a means for communities to present themselves in the public space of the towns and cities' (van der

\footnotetext{
${ }^{25}$ See $n .1$ above on the format of the newspaper. This entry appeared in the same edition and on the same page as the extract that opens this article. It was printed under 'Thursday, 16th June', and was surrounded by news of a case involving the poisoning of a pony above, and a complaint regarding bad driving on the Esplanade of an evening below.

${ }^{26}$ DeBernardi citing dd38 Penang Letters to the Governor, May-December 1863.

${ }^{27}$ Dressing as tigers has been noted in connection with Muharram commemorations in Surat, Gujarat (Sharif 1975: 159) and Iran (Arberry 1969: v. 2, plate 10b, cited in Feener 1999: n. 44), as well as in Singapore (Straits Times, 9 November 1850, p. 5).
} 
This is the accepted version of a forthcoming article that will be published by Taylor \& Francis in Indonesia and the Malay World: http://www.tandfonline.com/loi/cimw20

Accepted version downloaded from SOAS Research Online: http://eprints.soas.ac.uk/24486/

Putten 2013: 576; 2015: 206), but surely also a crucial site for the intermingling of musical and dramatic forms and the development of new tastes and practices in these areas.

In the Syair Tabut, we get a more nuanced perspective on inter-community relations in Singapore in the period and around the Muharram commemorations than that presented in colonial narratives which drew, by and large, a simple binary between the Red and White Flag societies, and saw the Muharram processions as nothing more than an opportunity for these societies to fulfill 'the principal object of their members ... to surpass their rivals in the grandeur of their public displays' (Singapore Free Press [henceforth SFP], 19 October 1865, p. 2). This being said, the contest for primacy between the various groups and their tabut, $k u d u$, or effigies is a major feature of the narrative. It is foregrounded early on in the Syair (q. 11):

Malam kesepuluh demi kelihatan

Habis dihias labu dan pekan

Tunggul panji-panji pun didirikan

Pangkat nan kudu pun dikenakan
On the tenth night it was seen at once

That bay and market were awash in decoration

The poles and flags were raised

And the order of the kudu determined

At the heart of the 1864 conflict was a contestation over space - which route the various tabut were paraded along - but also precedence. As emerges in Ali's Syair, and in reportage of the subsequent criminal trials, the processions focused around Telok Ayer, south of the Singapore river. 'Kampung Susu', in Ali's terms, or Cross Street, is the epicentre of the action, and testimony corroborates the circular routes that the various tabut usually took around Telok Ayer Street, Market Street, Kling Street, Circular Road, South Bridge Road, Cross Street, Amoy Street, Upper Macao Street, New Bridge, and Chincheu Street (SFP, 10 May 1866, p. 3). Tschacher (2010: 199), drawing on the newspaper coverage of both the Great and Police Conspiracy cases, describes 'three acts of ritual provocation of the "White Flags" by the "Red Flags"': taking precedence in the procession for the first time; marching in White Flag territory, that is, down Cross Street, in Telok Ayer; and the destruction of the White Flag's tabut by members of the Red Flag society. The Syair lets us view this event in all its complexity: a contest over 'ritual honours' (Tschacher id.), certainly, but one that involved distinct local territorial groupings - engaged, as Rai (2014: 56) suggests, in attempts to 'extend territorial control and influence over the Indian population in the settlement' - and also perhaps therefore ancestral, racial, caste, or community groupings within the societies. And it is this perspective that sheds some light not only on colonial accounts of Muharram, but also on inter-group relations in the period.

As Ali, the newspapers, and the court cases note, the Muharram processions were not confined to the kampungs south of the river, but apparently traversed the European centre of the settlement. When the processions set off, in quatrain 55, they move towards Kampung Gelam - an area to the northeast of the European area of Singapore, and home to predominantly Malay and Arab communities, as well as the 'Sultan of Muar' in his Istana. ${ }^{28}$ This traversing of the European quarter provoked another kind of conflict - one based on noise, rather than violence. The derisory attitudes to these and other festivals found in the newspapers of the period inform Jenny McCallum's fundamental contention that these

\footnotetext{
${ }^{28}$ The court case testimony records these travels in English, and so in English terms: '... over the Bridge into High Street passed the Court House along Beach Road into Arab Street along S.[outh] B.[ridge] Road to the river, where the Taboot is destroyed [or, rather, immersed]. The White Flag and Red Flag took the same routes White Flag preceded.' (SFP, 10 May 1866, p. 3). See our note on geography above.
} 
This is the accepted version of a forthcoming article that will be published by Taylor \& Francis in Indonesia and the Malay World: http://www.tandfonline.com/loi/cimw20

Accepted version downloaded from SOAS Research Online: http://eprints.soas.ac.uk/24486/

conflicts over noise 'originated in the encounter between communities with fundamentally different sonic ideologies’ (2017b: XXX).

However, as McCallum also argues, while European residents of Singapore might have preferred an absolute prohibition of 'noisy' Asian processions, 'the colonial government was forced to negotiate' with various groups, thereby acknowledging the power of the groups themselves and the value attached to 'parading sound in the streets' (ibid.). Ultimately, a professed wariness of interfering in the religious customs of the various populations in the Straits Settlements - a self-congratulatory and oft-repeated paean to supposed British liberality - succumbed to anxieties surrounding not only public disorder, but specifically secret societies and the imperium in imperio threat that, in the post-1857 period, they had increasingly come to be regarded as constituting. Indeed, Rai (2013: passim) has argued convincingly that 1857 marked a watershed moment in European attitudes to Indians in Singapore, whereby their public gatherings became distinctly threatening. Thus, in the wake of the Muharram commemorations recounted in the Syair, a trial was held of six senior members of the Red Flag society in October 1865 in what was reported, avidly, as the 'Great Conspiracy Case'.

The charge of conspiracy was levelled it seems primarily due to the Red Flag society's acquisition and use of funds, particularly in paying fines incurred by its members. The outcome and consequences of the case are well known in histories and studies of the Straits Settlements, particularly as they relate to the regulation of access to public spaces for religious rites. Turnbull (1972: 105-6) succinctly summarises:

... a Red Flag headman turned queen’s evidence against his society and surrendered documents and information which exposed its activities in extortion and oppression and led to the arrest and imprisonment of six Red Flag leaders. Cavenagh [the Governor] put a permanent ban on both the Muharram and Dusserah processions, after which the Indian societies ceased to menace Singapore's peace .... .

The SFP (19 October 1865, p. 3), remarked tartly, on the delivery of the verdict, that 'the Tamil Interpreter explained to those present the Judge's remarks which we trust will have a beneficial effect in breaking up entirely this and other societies which have been serious nuisances to the community at large and detrimental to public morals'. This comment was fairly representative of the paternalistic tone that the press frequently adopted in this period towards non-European races in the Settlements. But the trial of this case first threw up allegations against the police: foremost, of bribery, and the SFP (16 November 1865, p. 2) remarked that 'a petition signed by several hundred persons has been presented to the Government reiterating the charges of bribery against some members of the police force'; and secondly, the abrupt dismissal of one Deputy Inspector Burgess for assaulting a witness in the courthouse. Again, the press displayed their sympathies:

The recipient of Mr. Burgess' attentions had said much to involve the superior officers of the unfortunate Deputy Inspector ... we suppose he could not resist the opportunity of revenging himself upon one who had injured his brethren. Mr. Burgess, although guilty of a very grave offence, acted somewhat from motives that are not in general despised by his fellowmen [sic].

(SFP, 26 October 1865, p. 2)

They were clearly gratified, however, by the bulk of the petition, presented to the Recorder (Sir Richard McCausland) by some 250 'Klings', drawing attention to the tyranny they had suffered under the Red Flag society, and praising British justice - even if they also hoped to 
This is the accepted version of a forthcoming article that will be published by Taylor \& Francis in Indonesia and the Malay World: http://www.tandfonline.com/loi/cimw20

Accepted version downloaded from SOAS Research Online: http://eprints.soas.ac.uk/24486/

see it applied to the policemen who, they claimed, had ignored their previous complaints. The paper printed it in full. ${ }^{29}$

The sense that both this conspiracy trial, and the subsequent banning of Muharram processions, was in essence a public order move, and at best, a strike against secret societies, was widespread amongst the European population of Singapore, and has been replicated in histories ever since. Viewed generously, the cessation of noise associated with these processions that the ban entailed was an ancillary benefit to a population that had no genuine appreciation for or real tolerance or understanding of the public exercise of religion or customs other than their own. ${ }^{30}$ The extent to which secret societies loomed large in the fearful imagination of British colonists is nowhere better evidenced than in Mervyn Llewlyn Wynne's somewhat later Triad and tabut: a survey of the origin and diffusion of Chinese and Mohamedan secret societies in the Malay peninsula, AD 1800-1935, which, despite its manifold flaws, has become the go-to reference for studies of the issue. His meandering study - which takes in the origins of man, dualism, and conjectured links between the Knights Templar and the Hung League (Wynne 1941: 165-6) - does have value in terms of scope and the sheer breadth of citations of sources and opinions, especially those contemporaneous to the events we are considering. However, his fundamental contention regarding Muharram and the Red and White flag societies in Penang and Singapore was that they had 'formed an unholy underground alliance with the two Chinese camps respectively, the White with the Triad and the Red with "Tokong"' and that 'a way was found of making the position of the flag associations more secure by borrowing the cloak of the Muharram festival and using it as the explanation and excuse for their existence' (Wynne 1941: 190). ${ }^{31}$ Muharram processions, then, were no longer a genuinely religious exercise in this view, but had become a debased and corrupted pretence at piety, serving only to mask and invigorate criminality and tribalism.

We may note in passing several key points that emerge both in colonial policy making and the Syair. Firstly, we cannot ignore the apparently genuine devotional aspects of Ali's account. The involvement of the religious scholar (q. 4); blessings on the Prophet (q. 12); the help of the Prophet (q. 21); the praise of God (qq. 33, 35, 96); the heartfelt invocation 'Come then God, Creator of the World / The Believers are fighting for Islam' (q. 81; also qq. 103, 113); the cry to God (q. 101); and the palpable serenity of the end of the procession, the memory of 'the noble martyrs' (q. 124), the reading of the Fatiha (qq. 126, 136) and the sorrow associated with it: all points to a genuine religious and devotional experience that casts serious doubt on colonial aspersions on the true meaning of the ritual commemorations. Secondly, we really must question the law and order rationale for banning processions as a strike against the secret societies: to do so, we need look no further than the fact that Dusserah was simultaneously proscribed. And finally, we must take seriously complaints that

\footnotetext{
${ }^{29}$ In fairness, the editors were also concerned that a thorough investigation into allegations of corruption be conducted - 'We do not approve of the plan that, when a native accuses a public servant, especially if he be a European, of taking unauthorised rewards or bribes that, instead of the accused being put on his defence, the table is turned on the accuser and he is made the defendant' - though even this was couched, unsurprisingly, in racial paternalism such as 'The native mind is most sensitive and timid on some points ...' (SFP, 9 November 1865, p. 2).

${ }^{30}$ See also McCallum (2017b), who observes that British 'noise' - cannons, church bells, brass bands, etc. hardly merited the term in the colonists' world-view. For an excellent example of European disdain for all forms of native 'noise', see the long editorial comment in the SFP, 19 October 1865, p. 2.

${ }^{31}$ Contemporary commentators were also convinced that the Indian societies had sprung from the Chinese: see e.g. SFP, 1 June 1865, p. 2.
} 
This is the accepted version of a forthcoming article that will be published by Taylor \& Francis in Indonesia and the Malay World: http://www.tandfonline.com/loi/cimw20

Accepted version downloaded from SOAS Research Online: http://eprints.soas.ac.uk/24486/

viewed the banning of Muharram as an anti-Muslim, rather than particularly anti-Indian secret society action.

In what was presented as a Malay letter to the editor of the Straits Observer, and the newspaper's problematic and interpolating translation of the same, one Awang bin Mohamed complained some ten years later:

Jikalau Tuan bilang sebab gadoh, apalah sebab orang bangsah China buleh turot hadat iang buleh sukakah hati dia orang, saia fikir orang China ada bikin lagi gadoh, dan simpan dia orang punha hari raya lagi lama deri kita orang, kalau pulak sebab berkalai, orang puteh pun bila kotika hari tahon baruh atau lain lain dia orang ada juga banhak kali barkalai, mabok, dan bekin gadoh, jikalau buleh tangkap dan tutop sama orang puteh dan orang China jahat, kana apa tiada tangkap dan tutop orang Malayu iang jahat, supaia orang iang baik buleh soronokan hari nya kotika hari raya dia orang.

How is it then, Sir, may I ask, that we [Malays] are not allowed to enjoy ourselves in our great feast of the Moharrum? If you say it is on account of the noise, why the Chinese make more noise than we do, and besides their feasts last much longer. If it is on account of the disturbance, the Europeans during their Xmas and New Year's holidays, generally get drunk and fight each other on the street. Then why should we be the only nation prevented from enjoying ourselves on our great day? ${ }^{32}$

We cannot be certain that this was a Malay letter translated by the editors, as claimed. The author's professed familiarity elsewhere in the letter with the to-and-fro of that newspaper's correspondence from readers, much of which (not uncommonly for the time and place) was conducted pseudonymously, raises suspicion. Regardless, the humorous swipe at the hypocrisy of singling out Malays (and Indians) for censure while tolerating poor behaviour in Europeans is balanced by serious and nuanced critique of government policy in other regions of the Settlements, particularly the then ongoing Perak War that followed the killing of the British Resident (J.W.W. Birch) there in November 1875. It not only represents a strain of opinion that argued against the suppression of 'native' festivals by the colonial government, with allusions to the consequences of the failure of government officials to 'know the character of the Malays' (idem), but also strongly indicates the mixed participation of Malay and Indian Muslims in the Muharram commemorations, which were without doubt sincere expressions of religious devotion for many participants.

Crucially, Ali's Syair takes on a new importance in the context of the Police Conspiracy Case of April 1866. Perhaps the most remarkable aspect of this case was the interest it generated in the British community of Singapore, as evidenced in the extensive coverage it received in the SFP; the newspaper carried almost the full transcript of the trial, which took place on 16 April, in its weekly edition for four weeks, with a special supplement in the final edition. ${ }^{33}$ Tried by a jury, before the Governor (Colonel William Cavenagh) and the Recorder (Sir Peter Benson Maxwell ${ }^{34}$ ), four police officers - 'Messrs. Robertson, Hayward, Barnum, and Jemadar Verdarajen' - stood accused of conspiracy and corruption. The case was born out of the same events described in the Syair, the Muharram processions of June 1864, though it expanded to include subsequent allegations of corruption and collaboration between the

\footnotetext{
${ }^{32}$ Awang bin Mohamed, 'The Malays, To the Editor of the Straits Observer' and '[Translation] To the Editor of the Straits Observer', Straits Observer, 25 February 1876, p. 3.

${ }^{33}$ SFP, Criminal Session (19 and 26 April, 3 and 10 May 1866), Supplement, 'Hassan Hoossein' (10 May 1866).

${ }^{34}$ Charles Burton Buckley (1902: v. 2, 729-31), in his memoirs of Singapore, records Maxwell's appointment, along with brief biographical details on both him and the lawyers in this case, James Guthrie Davidson and John Simons Atchison. Buckley characterises them as 'the leading names in the bar in the Straits' who 'did the bulk of the work at the bar' (ibid.: 731). Davidson had defended the accused in the previous year's Great Conspiracy Case (Straits Times/Singapore Daily Times, 16 October 1865, p. 14).
} 
This is the accepted version of a forthcoming article that will be published by Taylor \& Francis in Indonesia and the Malay World: http://www.tandfonline.com/loi/cimw20

Accepted version downloaded from SOAS Research Online: http://eprints.soas.ac.uk/24486/

accused officers and the Red Flag society. The prosecutor, a Mr Davidson, presented the pertinent parts of the case to the jury thus:

On the 1st of June 1864 the unlawful society called the Red Flag Kongsee, whose object is to extort money from its members, who are all bound by oaths to secrecy, admitted Jemadar Verdarajen of the Singapore Police Force among their number. You are probably aware that the festival of the Mahomedans called Mohorrum is celebrated in the middle of June, ${ }^{35}$ and that the Red Flag, and White Flag, in their processions have different streets to pass through, so as not to molest each other. The evidence which you will hear, will inform you that the sum of $\$ 150$ was given to Mr. Robertson by the head man of the Red Flag society for his assistance to aid them in carrying their Taboot through streets which were thoroughfares reserved for the White Flag only .... .

(SFP, Criminal Session, 19 April 1866, p. 2)

He detailed the violence that had occurred when the Red Flag group took precedence over the White, and attacked the homes of White Flag men and 'destroyed a symbol of their religion'. And finally, for our purposes, he detailed the aftermath of the occasion:

The day following ... Mr. Robertson reported to Mr. Dunman [the Commissioner of Police] that the White Flag people had created a disturbance, and he therefore thought it necessary to arrest 42 to 45 of their men. These men were brought before the sitting Magistrate Mr. Vaughan, and Mr. Robertson appeared against them, and accused them of riotous conduct. They were placed in custody for several days, bail being refused, and you will remark that the Kongsee paid to Mr. Robertson during this time various sums of money, and monthly supplies of Gram, Paddy, \&c were sent to his house.

(SFP, Criminal Session, 19 April 1866, p. 2)

The prosecution proceeded to call a number of witnesses - notably, members of the Red and White Flag societies, including one 'Ninamsah', who testified that he had been a member of the Red Flag society from 1861 until May 1865 (SFP, ibid.) and was the chief witness for the prosecution.

The witness testimony in the trial corroborates many of the events that take place in the Syair: the close involvement of police officers in directing the procession; the allegation of assault against members of the procession (specifically, 'Mr Burgess committed an assault upon Mowlasah', ibid.); assault on White Flag property and the tabut by members of the Red Flag society (SFP, 10 May 1866, p. 5); bribes having been given to policemen, specifically Mr Robertson; and the direct intervention by Mr Robertson that held up the White Flag tabut procession and ordered the Red Flag to proceed down Cross Street, immediately after which the assault on the White Flag 'symbol house' occurred (passim, but particularly SFP, 19 April 1866, p. 2).

When in 1863 violence broke out between rival Chinese secret societies, Cavenagh quelled it in part through his innovation, widely praised in histories and memoirs, of appointing the headmen of the societies as special constables, 'the first time this very effective system was used in Singapore' (Turnbull 1972: 121). If the evidence of the Police Conspiracy Case stands, this method was repeated the following year with the Red and White Flag societies. What is clear is that the Straits Settlements authorities were only moved to intervene to inconvenience and, eventually, suppress these societies once their existence impeded on government activities and the lives of European settlers. As Turnbull dryly observes, 'the Chinese hoeys tyrannized only their own people and constituted no threat to the government' (ibid.: 122).

\footnotetext{
${ }^{35}$ Muharram shifts by approximately 11 days each year relative to the solar calendar: thus Ashura, or 10 Muharram, fell on 26 June 1863, 15 June 1864, 4 June 1865, 24 May 1866, etc.
} 
This is the accepted version of a forthcoming article that will be published by Taylor \& Francis in Indonesia and the Malay World: http://www.tandfonline.com/loi/cimw20

Accepted version downloaded from SOAS Research Online: $\underline{\text { http://eprints.soas.ac.uk/24486/ }}$

However, the most subversive element of Ali's Syair is in the direct and explicit attribution of blame for the violence. As we have noted, Ali is no fan of the Red Flag party of the ringin from Dhoby Ghaut. The key passage in his description of the conflict between the two parties comes in quatrains 117-18:

\author{
Ajaib fakir bukan buatan \\ Mereka berkelahi sebagai Syaitan \\ Merinyu seorang empunya hasutan \\ Maka demikian jadi perbuatan \\ Kedua pihak sama beraninya \\ Kompeni Inggeris tiada diendahnya \\ Palu memalu sama keduanya \\ Ditangkap Kompeni seraya ditutupnya
}

\author{
The fakir was truly amazed \\ They were quarrelling like the Devil \\ The inspector himself provoked them \\ And that is why it turned into a scene \\ Both sides were equally brave \\ They ignored the English Company \\ Both were beating each other \\ And were caught by the company and arrested
}

It was, in Ali's understanding, the fault of the police that the quarrel got out of hand. What we see here is a strong Malay critique of police methods. It recurs in quatrain 135c-d:

Lima orang merinyu Kompeni

Dengan perang mereka layani
Five inspectors of the Company

They acted with aggression

Perhaps even more explicitly, Ali blames the European police inspectors for almost all the serious violence that later featured in the Police Conspiracy Case trial: 'One of the inspectors was responsible' for the destruction of the White Flag tabut (q. 91); an inspector, when hit by a stone, 'unsheathed his sword' and then 'commanded the ringin', or the Red Flag members, 'to hit the bibadal', and in his ferocity ordered the attack on the White Flag house (qq. 93-5); he then assaulted people, and had them arrested (Ali perhaps overestimates the numbers at 'around a hundred'). Certainly, for Ali, this rather spoils the moment for almost everyone, for 'The inspector alone was having fun' (qq. 96-8). In the elliptical structure of the Syair's narrative, the inspector returns again and again, and the recurring theme is his absolute culpability for instigating and exacerbating the violence between the two societies. We can compare this sentiment with that in the quotation from the Straits Times that opens this section, wherein the police are the thin blue line that separates the colony from an orgy of violence. The bias of European accounts should hardly surprise us, but only comes into such clear relief when there are other, native, vernacular accounts against which to read them, such as the Syair.

The result of the trial was, perhaps, predictable. The defence case traded in unsurprising, racist stereotypes ('Are Klings actually silent about wrongs?'), while the Governor's summation and instructions to the jury was distinctly leading ('it is well known that no member of Police ... should be capable of receiving a bribe in any shape or form'; 'how can we suppose for a moment that a man such as Mr Robertson, and Mr Hayward, could be induced to depart from the straight line of duty by a trifling matter') and galling in his ascription of superior morality to the European gentleman:

Some people are fonder of telling lies than others; but if there is one thing more than any other which distinguishes the English nation, or indeed we may say any European nation generally from all others, it is their respect for the truth.

(SFP, Supplement, 10 May 1866)

It should come as no surprise then that the jury found the accused not guilty, though it 'considered that Mr. K.B.S. Robertson and the Jemedar had acted with culpable indiscretion'. 
This is the accepted version of a forthcoming article that will be published by Taylor \& Francis in Indonesia and the Malay World: http://www.tandfonline.com/loi/cimw20

Accepted version downloaded from SOAS Research Online: http://eprints.soas.ac.uk/24486/

As the report concluded, 'this decision was received with much applause in the Court' (idem).

Although not a witness in the trial, Encik Ali was a witness to the events, and he is explicit: the police had taken bribes to facilitate the transgression of long established norms of conduct by the Red Flag society; the European inspectors were beholden to that group, and had taken their side against the White Flag members; not only that, but the British officers had been instrumental in provoking and inflaming the confrontation. Of course, Ali is linked to the White Flag society - if not a member, then perhaps by geographical affinity or allegiance and makes it clear throughout the Syair where his sympathies lie. This is not to say that his account is ipso facto untrustworthy, but reminds us to view it as testimony. As we have seen throughout, it is also constantly qualified. That said, the Syair is much more than merely a record of events in a vein of reportage or witness testimony; rather, we must be, as he was, attentive to the performative and literary nuances of the spectacle of Muharram, to the never quite recoverable experiential quality of those events for participants, and to the ways in which these are conditioned by and enclosed within the text itself. Stripping the Syair of everything but the facts it reveals to history misses the point.

\section{Paper faces on parade: music, vernacular public spheres, and the masquerade}

The geographical exercise we have concluded above has placed us amidst the turns and boundary lines of Singapore's map; reading the stanzas of the Syair, we can't help but see Ali there too, standing on the side of the road to observe, relate, and transform the procession into poetry. After the Red and White Flag parties have been organised (qq. 15-20), the poet describes a wide range of performances in sensory language. He appears to stay still as the performers pass by, hard on each other's heels: a fierce warrior (q. 24); skilful dancers from Penang (q. 26a-b); a violin-playing Burmese general (q. 26c-d); a party of Klings 'shining black like starling birds' (q. 27b); and last of all, a troupe formed of the 'sons of Bengkulu' (qq. 28-9):

\author{
Dengarkan pula suatu peri \\ Lancang yang akhir sangat bahari \\ Gendang serunai rebab nafiri \\ Dipalu mereka tiada terperi \\ Itulah pasukan anak Bangkahulu \\ Elok majelis sangat terlalu \\ Biola digesek tambur dipalu \\ Seraya berseloka berbagai lagu
}

\author{
Now hear the story of \\ The last boat, very seaworthy \\ Drum, shawm, bowed lute and trumpet \\ How they played them all is beyond telling \\ That troop was the sons of Bengkulu \\ They were astoundingly handsome \\ The violin was bowed and the drum beaten \\ Followed by sung poetry to a variety of tunes
}

This 'last boat' has pride of place in the tableau, filling two quatrains, which in turn reveal two elements of traditional Malay culture that underwent a transformation in the 19th century: the music of ritual ensembles, and the recitation and audition of poetry.

Malay listeners from the Singapore-Riau area would have recognised three of the instruments in the last boat - the gendang (drum), serunai (shawm), and nafiri (long metal trumpet) - as constitutive of the exclusively regal nobat ensemble, described as they are in precise terms that stand out from the more generic words used for music from further afield (the 'biola' of qq. 26c, 33a). Along the Straits of Malacca, the strains of the hereditary musicians played the sultan onto his throne and off from his deathbed, and signalled the royal presence at the 
This is the accepted version of a forthcoming article that will be published by Taylor \& Francis in Indonesia and the Malay World: http://www.tandfonline.com/loi/cimw20

Accepted version downloaded from SOAS Research Online: http://eprints.soas.ac.uk/24486/

palace or on the road to war. ${ }^{36}$ It is the musical kin of the word bibadal, conferring a prestige shaped by an exalted Islamicate civilisation, although its long presence in the Malay world from the 14th century meant that its strains no longer required translation. Yet though the nobat was intelligible, it was also meant to be inimitable: the ensemble's prestige was linked to its transmission through more powerful regimes arcing back to central Asia, and its instruments were only allowed to be touched by hereditary musicians at proscribed times (sometimes, on pain of a magical death). ${ }^{37}$

The presence of the nobat instruments in a float in a street-level parade, then, signals an overlapping of spheres; an attentive reader would have spied the rebab, or spike fiddle, amongst the gleam of the royal ensemble - an instrumental interloper with a broad membership in popular, and traditional, and courtly ensembles throughout mainland, peninsular, and maritime Southeast Asia. ${ }^{38}$ Certainly, in 19th-century Singapore, there was no powerful monarch to take exception as the sultanates of the straits were but a shadow of their previous selves: 'Ali of Johor', living in Kampung Glam, was a sultan without sovereignty who lived in palace without a court. ${ }^{39}$ The presence of this hybrid ensemble in the Muharram procession would have evoked - in spectator and reader - the regal associations of the nobat, even as it pointed towards the ever increasing diversity and hybridity of performance practices and contexts in the city and, indeed, the region. Perhaps this is only natural in such a cosmopolitan and mobile setting as colonial Singapore, then, less than fifty years old.

And the description of the nobat is not the only such upending - near the end of the Syair, in quatrain 123, the poet writes of a Malay champion, that

Susunan Belacan dastarnya

Muncung Melayang ikatan kainnya

Pencawarna akan salurnya

Payung Sitin akan naungannya
His headgear was called 'Shrimp Paste Arrangement' His sarong knot was called 'Floating Snout' Multicoloured were his trousers

'Satin Umbrella' was his shade

If the Syair's readers were unfamiliar with the naming conventions of Malay regalia, the covering umbrella - an unmistakable regal emblem of the Indic and Islamicate worlds brings home the point. Except that in this case, the umbrella does not cover a king, but a reveller marching down Singapore’s streets; 'Shrimp Paste' is not a normal name for a cloth

\footnotetext{
${ }^{36}$ See Andaya (2011: 24-6).

${ }^{37}$ Poetry is one of the few written sources we have for this transmission. The 14th-century Hikayat Raja-Raja Pasai narrates how the ruler of a kingdom in coastal north Sumatra obtained the ensemble by boat only after his conversion to Islam. See Raja Iskandar (2015: 79-81, 232) for a discussion of the hikayat, the hereditary nature of nobat musicians, and consequences of instrumental misuse.

${ }^{38}$ The rebab, too, can claim a Middle Eastern ancestor - the spike fiddle or bowed lute (Hornbostel-Sachs number 321.31) of the Arab musical world (which is different again from the plucked, Central Asian version of the same name). As a representative list of Southeast Asian ensembles that contain the spike fiddle, consider the courtly ensembles of Javanese gamelan and Thai khrueang sai; the genggong dance from Lombok, the Kelantanese main putri healing ritual, and Malay pencak silat martial arts; sung poetry from Java, Sunda, and the Minangkabau lands; and shadow puppet traditions throughout the region.

${ }^{39}$ Sultan Ali (r.1855-77) was the son of Sultan Hussein Shah, who famously signed the 1824 treaty that allowed for the founding of colonial Singapore. Although Sultan Ali was Sultan of Johor in name, he was not recognised as such by the British, and Abu Bakar, the Temenggong of Muar (a hereditary position usually granted by the sultan) maneuvered himself into position as the sovereign leader. Interestingly, Abu Bakar's amenability to British interests was likely formed by an education at the missionary school of Rev. Benjamin Keasberry, the patron of the press that published the Syair Tabut in lithograph form. See Turnbull (2009: 232-4).
} 
This is the accepted version of a forthcoming article that will be published by Taylor \& Francis in Indonesia and the Malay World: http://www.tandfonline.com/loi/cimw20

Accepted version downloaded from SOAS Research Online: http://eprints.soas.ac.uk/24486/

adorning the most exalted place on the body, the head. ${ }^{40}$ In one quatrain, the poet skilfully tips his description into farce and out again, but the joke trades in the dispersed knowledge of specifically Malay customs. So too, in the description of the nobat, Ali may be using connotations of the regalia only metaphorically, or tongue in cheek, to cast a regal glow on the humbler instruments and outfits of his favoured Malay performers. At the very least, this sonic and sumptuary confusion points to courtly protocol that, though still intelligible, is in considerable flux.

Indeed, these social transformations raise questions about the performance context of the syair itself, the poetic apogee of courtly audition, with its 'whirl of euphonic effects' (Braginsky 1999: 140) wholly worthy of any 'variety of tunes'. Proudfoot (2002: 123) states that 'the meaning of a text could be conveyed effectively only in performance', describing syair that 'were sung to a range of melodies, sometimes with musical accompaniment'. In her survey of the sonic Malay world, McCallum dwells on the Hikayat Hang Tuah from the turn of the 18th century, the recitation of which would necessarily feature nested performances: the description of a character reciting poetry for the Sultan, 'skilled at producing a voice that made all moved' (McCallum 2017a: 105), would have in turn been voiced in ways compelling to an early 18th-century reciter and audience.

So too, at the end of the description of the Malay procession, Ali uses his poem to describe how 'the violin was bowed and the drum beaten / Followed by sung poetry to a variety of tunes' (q. 29c-d). Poetry attached to Muharram brings to mind the Persian elegies called marsiya, which transformed the events of the Battle of Karbala into literary bereavement, and were intoned throughout the Indian subcontinent. Yet Ali's Syair is not that. In writing about the 1815 Syair Perang Inggeris Di Betawi, a poem from 50 years earlier, Ben Murtagh (2002: 34-5) provides a likelier model when he remarks on 'a shift ... from the sphere of the court to the sphere of the kampung', from the aristocratic enclaves to an emerging public sphere, predictable but particular. ${ }^{41}$ The setting for the poem - British Java - was a place that did not exist after the 1814 Convention of London. But like Singapore in 1864, Batavia was grappling with European power shifts that prompted changes in the medium of the poetry, and a military intervention in its content. Ali's Syair also grapples with events of civic consequence, in conflict with an expanding colonial power whose administrative reach extended ever further into the lives of its subaltern subjects. We can only imagine how or even if Ali's 1864 lithograph-manuscript would have been voiced and heard - yet even so, sound is latent in its every rhyme.

By the mid 19th century, then, the syair had become a part of the increasingly hybrid public sphere in which a broad set of discrete audiences accessed a variety of cultural forms, brought together by recent colonial and pervasive regional circulations, in a number of languages, including the musical. Ali on the street corner, watching the performers go by, represents one individual within this alternative audience as much as he is a poet in a storied literary lineage, and Singapore's Muharram masquerade is the perfect moment to document both his ear and his voice. Take, for instance, his Syair's brief description of a performance by a Thai musician (q. 33a-b):

Seorang Siam menggesek biola

Terlalulah elok Subhanallah
A Siamese played the violin

Glorious is God! it was too beautiful

\footnotetext{
${ }^{40}$ The absurdist naming conventions are reminiscent of Sharif's descriptions of masquerading in South Indian versions of the Muharram, see in particular (Sharif 1975: 172-81).

${ }^{41}$ Of course, there is a much longer tradition of writing 'historical syair', see e.g. Kathirithamby-Wells (1980).
} 
This is the accepted version of a forthcoming article that will be published by Taylor \& Francis in Indonesia and the Malay World: http://www.tandfonline.com/loi/cimw20

Accepted version downloaded from SOAS Research Online: $\underline{\text { http://eprints.soas.ac.uk/24486/ }}$

Here, the 'violin' shows Ali grasping at the familiar to describe the novel, ${ }^{42}$ shown in his vocabulary of astonishment in the second half of the couplet. The poet seems deeply impressed by the music; he recruits the language of literary affect with the Malay descriptions elok mejlis and merdu ('lovely' and 'melodious'), long used to describe beauty in poetry. ${ }^{43} \mathrm{He}$ ends in reverent wonder with the Arabic interjection 'subhanallah', 'glory to God'.

The Thai musician is unique, but he or she is not alone: besides the Burmese and Penang dancers mentioned above, the parade includes Javanese, Boyan, Indian, and mixed-race groups. The crush of difference here, brought into proximity by colonial interventions, invites a wide-flung comparison with diverse parallel masquerades that also ended in discord; the cast of characters of Trinidad's Hosay massacre of 1884, for instance, included indentured Indian Muharram masqueraders, Creole drummers, and Chinese workers, all of them affected differently by the violence of the colonial regime. ${ }^{44}$ The performative connections are easy to draw and their theoretical promise well rehearsed - alternative public spaces, inverted conventions, sounds and performances that cross boundaries and butt up against constraints especially when we know how the Singapore Muharram events were eventually translated into the legal codes and published columns of the colonial British. But we need not always scope out, to see the carnivalesque and its resistance and comic subversion, writ large. The musical activity of each group, present and playing for their own reasons, also offers a chance for us to imagine many listening individuals, each caught up in their own sensory experience of multicultural urbanity.

When he sees the Thai musician pass, then, the son of Bengkulu is listening, deeply, to an individual whose 'otherness' is partially mitigated by his artistry as he draws bow across string; whether Ali can understand his musical language or not has no bearing on his ability to interpret it for himself. The translations do not stop there; Ali the poet can usher the subhanallah into the readers' minds and onto their tongues - likely even yours. We can imagine him first listening, uttering the reverent phrase sotto voce in an unbidden testament to the diversity of divine beauty. Perhaps the words were re-voiced upon writing, and then again with each subsequent recitation, the hush of syllables recalling the sonic emotion at its origin. Scholars of auditory cultures pay attention to the changeable quality of sound as musicians approach, then round the corner into other city streets; musicologists have long seen the recitation of Arabic texts to be as musical as any regal, ritual ensemble. Ali's poem certainly captures the spectacle of Muharram and its subversive potential that so raised the ire of newspaper readers. Yet his phrase of wonder is one of our nearest approaches to Malay sonic notation. It is recording and urtext at once - a wash of difference, captured at an individual vantage point, meant for a local audience yet ultimately open to many listeners.

\footnotetext{
${ }^{42}$ The word biola is a term that is curiously both familiar and foreign, used to describe the instrument brought by the Portuguese that nevertheless became thoroughly integrated into Sumatran folk music. See Kartomi (2012: 244-5) for a discussion of a reference to the biola within an Acehnese court hikayat in the early 18th century.

${ }^{43}$ On 'merdu as the sonic aspect of beauty', see McCallum (2017a: 103), drawing on the work of Braginsky (2004: 247-69), in which he argues for the term to be read as a synthesis of Malay aesthetics and Sufi metaphysics.

${ }^{44}$ See Korom (2003: 106-9) for a discussion of the integrated nature of the Hosay Muharram tradition in Trinidad in the years leading up to the violence in San Fernando, when nine were killed and 100 wounded after putting on a Muharram festival following a colonial ban. Korom notes a 'process of co-opting Hosay for numerous agendas' (ibid.: 108), that included Afro-Creole and Chinese participants, as well as Sunnis, Hindus and Christians.
} 
And if these listeners include scholars, what insights can paying attention to the performative in Ali's poem provide? We can think of two, both related to the moment when the musical groups pass into view: that the modern assumptions of bounded ethnicity are not borne out by Ali's poem; and that the temporary subversion of or resistance to colonial norms never was quite the point of this particular 'carnival'. In her thorough study of Singapore's urban landscape, Anoma Pieris (2009: 45-6) suggests that the 'tightly knit residential enclaves' of Singapore were intentionally planned, 'necessary to prevent the blurring of the different cares and conditions by which the colonial government's relationship to each racial group had been negotiated'. Seventy years earlier, Wynne (1941: 218), a former member of the Straits Settlements police force, saw similarly bounded communities when he suggested that the 'Tamil' Muharram societies were duped by 'two Chinese camps ... doubtless both angling for the support of such influential Mohamedans as they could attach to themselves with the bait of a truncated Chinese ceremony'. By this logic of (notably dull or conniving) racial groups existing in defined spaces, a procession that breached and traversed the carefully devised kampung boundaries was a dangerous prospect requiring intervention, 'to prevent the different races combining for anticolonial resistance' (Pieris 2009: 37). And yet, as argued above, the colonial government did not move to constrain the Muharram procession until it began to impinge upon Western space and Western ears.

Instead of bounded communities, the Syair consistently suggests linguistic, musical and affiliative mixture. Every time we were tempted to assume that the Dhoby Ghaut ringin was Tamil, and their antagonists, Bengkulu Malay, we would run up against quatrains like 34a-b, 'The leader was said to be a Kling / And all in the squadron were mixed-Malay', or even more telling, a description of this very group's music: 'They left out the Jawi song / Exhibiting the Bengali language' (q. 35c-d). Ali’s musical listening practice - to the Siamese violinist, but also to any number of performers he hears with opened ears - suggests that boundaries were permeable not only by a route, but by human, artistic engagement across the lines of language, ethnicity and religion. It is easy to code a transgressive route as an act of resistance; it is rather more difficult to ascribe political animus to a personal aesthetic judgment. The Syair shows people from across communities entangled in one another's lives, and listening to each other, intently. ${ }^{45}$ With such intention, in fact, that we cannot assume that Bakhtin's 'world turned upside down' would have righted itself with the rising of the next crescent moon.

\title{
Conclusion
}

The editors of the Singapore Free Press were in a jubilant mood when the Governor of the colony decided to ban Muharram processions just under a year after the events of 1864:

\begin{abstract}
The death blow has been struck at the Kling Hoeys by Colonel Cavenagh's determination to put a stop to all processions at the Mohorum [sic]; without them these societies must cease to exist, for their sole object is the celebration of that festival with as much pomp and splendor as possible. ... As these processions oft lead to street fights and bloodshed we rejoice that they have been deprived of the chief outlet for the display of their vicious propensities.
\end{abstract}

(SFP and Mercantile Advertiser, 1 June 1865, p. 2) ${ }^{46}$

\footnotetext{
${ }^{45}$ As Sykes (2015: 487) observes as regards Indian music making in colonial Singapore, 'boundaries of genre and ethnicity were constituted and crossed, by Indian and non-Indian musicians alike’. The Syair suggests an extension of this formulation across Singapore's communities and kampungs.

${ }^{46}$ The column contained the short text of the Commissioner of Police's order, dated 19 May 1865, which 'has been translated into the native languages and freely circulated among the people'. 'Kling Hoeys' is, of course, a
} 
This is the accepted version of a forthcoming article that will be published by Taylor \& Francis in Indonesia and the Malay World: http://www.tandfonline.com/loi/cimw20

Accepted version downloaded from SOAS Research Online: $\underline{\text { http://eprints.soas.ac.uk/24486/ }}$

In an account four months later, after the conclusion of the Great Conspiracy Case, the newspaper would go on to assert confidently that 'the natives rejoice at the result' (SFP, 19 October 1865, p. 2). Now that we have seen the challenges that the Syair Tabut puts to the 'disinterested' account, it is difficult not to wonder how Ali or his readers might answer back to that congratulatory coverage, and perhaps bear witness of a different sort. The term 'witness' is most at home in a court case, where testimony is marshalled and tapped into neat sheaves of paper. Many of Ali's statements could easily be pressed into service - the routes he details through urban Singapore, his chronology of events, his description of vandalism. Yet what work do his statements of wit and whimsy perform, as when he describes young girls willing to let their rice burn in order to see the spectacle, mentions a rainbow-hued woman disguised as a man, or records the shouts of 'pimp' directed at the leader of the White Flag group?

This last instance is corroborated in the court testimony of the Police Conspiracy Case, when discovery shows that a Tamil White Flag society member operated a beer house in a brothel. ${ }^{47}$ But we would be remiss if we did not stress that in the Syair, the testimony was first a bit of throwaway dialogue. Occurring in the introductory stanzas, before we knew what the tension portended, it served to set the scene, to bring to surface salacious kampung gossip, and to enliven the imagination of the reader - it was a performance detail, turned into corroborative fact. Corroborative facts such as these feel necessary because Ali is not bound by his profession to tell truth; he aims to tell a compelling story. He shows bias - the Bengkulu group is 'astoundingly handsome' (q. 29b); 'brave and tough without precedent' (q. 51d). And yet, the poet's descriptions have convinced us that he is describing real sound and real emotions, with a breathlessness that recalls the field notes of a working ethnomusicologist. In an unexpected way, this expansive veracity when so little is at stake endows Ali with the ethnographic authority of 'being there', and amplifies his later, serious allegations. There is poetic justice in the fact that a piece of Malay literature offers a key to understanding a historical event, especially considering the assertions of Presbyterian missionary Benjamin Keasberry, the patron of the press that printed our scroll, that Malay hikayat histories 'are only the products of the Malay mind, they are not established in truth' ${ }^{48}$ And yet, this poem is ceded space in this journal issue precisely because it is poetry rather than prose. Its credibility is established in the vernacular, and the audience it intends to convince aspires to read with 'the Malay mind.'

Our approach in both the translation and analysis of the Syair Tabut has been conditioned by a diverse range of sources and interpretative aids, which have consistently returned us to the cultural and linguistic multiplicity of Ali's opus. For instance, with barua, it is one thing to know that the word has Hindustani origins, and came eventually to hold the same insulting connotations in Indonesian; it is another thing entirely to watch that transmission in almost

curious construction, but the production of casual conflations and spectacular inaccuracies is hardly confined to the print media of the 19th century alone. The term is an Anglicisation of the Mandarin hui (會; Hokkien hoe), referring to the 'associations' or 'secret societies' (hei shehui, 黑社會) of the Chinese in the Straits Settlements. The existence of Malay and/or Indian societies on the model of the Chinese groups, and 'alliances' between them, is attested by contemporary observers and generally accepted in more recent scholarship (see e.g. DeBernardi 2004: 84-5).

${ }^{47}$ See note to q. 20b in the transcription (Byl et al. 2017).

${ }^{48}$ See Milner (2002: 62) who cannot determine whether these words were written by Keasberry himself, or translated at his impetus from another source; in either case, he certainly endorsed the sentiment when he was disseminating it from Bukit (Mount) Zion. 
This is the accepted version of a forthcoming article that will be published by Taylor \& Francis in Indonesia and the Malay World: http://www.tandfonline.com/loi/cimw20

Accepted version downloaded from SOAS Research Online: http://eprints.soas.ac.uk/24486/

live action, adding a rich layer to knowledge thus far obtainable only through dictionaries, superlative works as they may be. But it is something on a different scale altogether to consider the wider associations of the term, and the mechanisms by which it came to cross the Bay of Bengal. Indeed, the association of the term with the mridangam musician accompanying courtesans or 'nautch girls', and acting as the troupe's manager and therefore as a pimp, pushes us to excavate the history of the movement of these people through the region, and recall the baggage with which they travelled: cultural, literary, linguistic, and musical. In a similar vein, a thorough reading of Ali's Syair has been made possible only through the recruitment of sources quite distinct in their intentionality and production context. For instance, Ja'far Sharif's Qānūn-i Islām, a colonial ethnography par excellence, produced under the direction of Herklotts and translated by him to help the British in India better understand their Muslim subjects, gives us an array of details that, on occasion, read as almost too fanciful to have been true. So many of these, however, are corroborated not only in our poetic account of 1864 in Singapore, but also by near contemporary artistic production in the form of the 'Muharram scroll', exhibited by Sam Fogg and the American Federation of Arts (Butler-Wheelhouse 2016: cat. 38; Welch 1978: cat. 69; see Figure 4). Be it rainbowschemed decorations, animal-shaped masquerading that had no place in an 'orthodox' (or might we say Protestant?) understanding of mourning ritual, noise-making instrumentalists of various types including tasa drum and bowed lute, or the bizarre play-fights pitting tigers against weapon-wielding fakirs in close proximity to standards of 'Alid piety: reading the action in the painted scroll against the description in the poetic one allows us to see these traditions as connected, and indeed, coherent.

[Image available in published version]

Figure 5 'Muharram processional scroll (detail), South India, probably Madras, c. 1830-40'. Courtesy of Sam Fogg, London. The scroll is now in the collection of the Asian Civilisations Museum, Singapore.

Stephanie Newell's elaboration of the 'paracolonial' has been crucial to our and our colleagues' approach to the study of the musical and epistemological traditions of the region. We have tried to draw out 'the many otherwise unaccountable regional musical practices and knowledges that coexisted, waxed, and waned in differing relations to European power and culture during ... the colonial period' (Schofield 2016). The prefix is key here - it allows us to move outside a discourse of pre- and post-, oriented towards an appreciation of 'local cultural productivity which undoubtedly took place over the generations, alongside and beyond the British presence in the region, as a consequence of the British presence, but not its direct product' (Newell 2001: 350). Paracolonial instances jostle within the Syair - drawing their spirit from an older tradition, unintelligible to colonial knowledge, resulting in curious configurations. When the Muslim bibadal of the White Flag society claims to be Tok Betara - the Malay title for the Lord Shiva - in contradistinction to a group made up partially of Tamils who had lived in South Asia only decades before, you can see older and younger traditions of Indian Ocean movement at once, with colonial signifiers in the hazy background if visible at all.

Substantial humility is necessary when attempting to document - sometimes, at most, to only imagine - the paracolonial, a set of practices and experiences rendered opaque to us by its own definition. This requirement is compelled by a number of limits imposed by our project: 
This is the accepted version of a forthcoming article that will be published by Taylor \& Francis in Indonesia and the Malay World: http://www.tandfonline.com/loi/cimw20

Accepted version downloaded from SOAS Research Online: $\underline{\text { http://eprints.soas.ac.uk/24486/ }}$

our dependence on happenstance in encountering the text itself as well as supporting sources; the simultaneously rich and yet impenetrable qualities of those sources; even our inability to fully decipher the manuscript hand at the end of the Syair. For an explanatory coda, consider the following description of the 'native' reactions to the pending conclusion of the Great Conspiracy Case.

From the day the criminal sessions opened prayers have been offered up at the Telluk Ayer Mosque, to which the prisoners belonged, for their acquittal ... On Friday, a Kling man and woman were seen passing the Police Court in a hack gharry at a slow pace strewing boiled rice out of the windows above the road for good luck.

(SFP, 13 October 1865)

Devotion born of urgent need may be opportune but is not of necessity insincere. When considering the significance of this street-level performance of strewing rice, we as scholars naturally inventory of all of the multitudinous customs of South and Southeast Asia; when considering the ornamented voices raised in concert, we recall what we think we know about Muslim piety. Yet what these performative utterances meant to the people who enacted them is almost inscrutable, filtered, as they so often are, through the lens of colonial sources. This is a good reminder to take into an engagement with a vernacular source as well. And so our reading of Encik Ali's Syair Tabut, accessed and encountered only through great fortune, is offered as a corrective that can only be partial and contingent.

\section{Acknowledgments}

We are particularly grateful to the National Museum of Singapore/National Heritage Board, University Library Leiden, The National Archives (UK), and Sam Fogg for their generous permission to reproduce images, and respectively to Tan Chor Koon, John Frankhuizen, Hugh Alexander, and Andrew Butler-Wheelhouse for their assistance. We would like to thank Annabel Teh Gallop, who gave generously of her time and pointed out several important features of the Syair's publication context, Katherine Butler Schofield, Michael Talbot, and Francesca Orsini for reading drafts of this article, as well as our collaborators in the transcription and translation of the Syair Tabut, Raja Iskandar bin Raja Halid and Jenny McCallum (along with all our collaborators and critical friends on the 'Musical Transitions' project), without whom we would not have been able to do what little we have done here. The editors at Indonesia and the Malay World have been particularly supportive of this rather substantial publication effort, and we count ourselves fortunate to have had such encouragement and such a forum. And last, though by no means least, we thank the anonymous reviewers for the journal, whose detailed, careful, and constructive feedback on both this article and the Syair could hardly have been surpassed. As always, any and all mistakes and deficiencies remain our own.

\section{Funding details}

This work was supported by the European Research Council under the project 'Musical Transitions to European Colonialism in the Eastern Indian Ocean' (2011-15, King's College London, PI Dr Katherine Butler Schofield, Grant no. 263643).

\section{Note on contributors}

David Lunn is the Simon Digby Postdoctoral Fellow at SOAS University of London. His research interests span the literary, cultural, and intellectual history of modern South and, 
This is the accepted version of a forthcoming article that will be published by Taylor \& Francis in Indonesia and the Malay World: http://www.tandfonline.com/loi/cimw20

Accepted version downloaded from SOAS Research Online: http://eprints.soas.ac.uk/24486/

increasingly, Southeast Asia, with a particular focus on the politics of language. Email: dl24@soas.ac.uk

Julia Byl is Assistant Professor of Ethnomusicology at the University of Alberta. Her research interests have centred around musical performance in north Sumatra, and have recently spread to the broader Malay world and to East Timor, where she is beginning a study of music, the individual and the institution. Email: jbyl@ualberta.ca

\section{References}

Archive, National Library of Singapore

Singapore Free Press (SFP) (/and Mercantile Advisor)

Straits Times

Straits Observer

Ali, Hj Wan Mamat. 1985. Katalog manuskrip Melayu di Belanda/Catalogue of Malay manuscripts in the Netherlands. Kuala Lumpur: Perpustakaan Negara Malaysia.

Andaya, B. 2011. Distant drums and thunderous cannon: sounding authority in traditional Malay society. International Journal of Asian Pacific Studies 7 (2): 19-35.

Arberry, A.J. (ed.). 1969. Religion in the Middle East: three religions in concord and conflict. Cambridge: Cambridge University Press.

Braginsky, V. 1999. Towards the biography of Hamzah Fansuri. When did Hamzah live? Data from his poems and early European accounts. Archipel 57 (2): 135-75.

Braginsky, V. 2004. The heritage of traditional Malay literature: a historical survey of genre. Leiden: KITLV.

Braginsky, V. 2008. 'Spun within the brain, woven in the heart': R. J. Wilkinson's survey of traditional Malay literature and its overarching task. Indonesia and the Malay World 36 (106): 417-28.

Buckley, C.B. 1902. An anecdotal history of old times in Singapore. Singapore: Fraser \& Neave.

Butler-Wheelhouse, A. 2016. A library of manuscripts from India. London: Sam Fogg.

Byl, J., Raja Iskandar bin Raja Halid, Lunn, D. and McCallum, J. 2017. The Syair Tabut of Encik Ali: a Malay account of Muharram at Singapore, 1864. Indonesia and the Malay World 45 (133): XXX-XXX.

DeBernardi, J. 2004. Rites of belonging: memory, modernity and identity in a Malaysian Chinese community. Stanford CA: Stanford University Press.

DeBernardi, J. 2006. The way that lives in the heart: Chinese popular religion and spirit mediums in Penang, Malaysia. Stanford CA: Stanford University Press.

Feener, R.M. 1999. Tabut: Muharram observances in the history of Bengkulu. Studia Islamika 6 (2): 87-130.

Feener, R.M. 2015. 'Alid piety and state-sponsored spectacle: Tabot tradition in Bengkulu, Sumatra. In C. Formichi and R.M. Feener (eds), Shi 'ism in Southeast Asia: 'Alid piety and sectarian constructions. London: Hurst, pp. 187-20.

Gallop, A.T. 2015. A Jawi sourcebook for the study of Malay palaeography and orthography: Introduction. Indonesia and the Malay World 43 (125): 13-39.

Haughton, H.T. 1891. Native names of streets in Singapore. Journal of the Straits Branch of the Royal Asiatic Society 23: 49-65.

Iskandar, Teuku. 1999. Catalogue of Malay, Minangkabau, and South Sumatran manuscripts in the Netherlands, vol. 1. Leiden: Documentatiebureau Islam-Christendom. 
This is the accepted version of a forthcoming article that will be published by Taylor \& Francis in Indonesia and the Malay World: http://www.tandfonline.com/loi/cimw20

Accepted version downloaded from SOAS Research Online: http://eprints.soas.ac.uk/24486/

Kartomi, M.J. 1986. Tabut - a Shi’a ritual transplanted from India to Sumatra. In David P. Chandler and M.C. Ricklefs (eds), Nineteenth and twentieth century Indonesia: essays in honour of J.D. Legge. Clayton: Monash University, pp. 141-62.

Kartomi, M.J. 2012. Musical journeys in Sumatra. Urbana IL: University of Illinois Press. Kathirithamby-Wells, J. 1980. A note on Malay 'historical' writings in Benkulen during the British era. Indonesia Circle 8 (22): 24-31.

Korom, F.J. 2003. Hosay Trinidad: Muharram performances in an Indo-Caribbean diaspora. Philadelphia PA: University of Pennsylvania Press.

Kratz, E.U. 1981. The editing of Malay manuscripts and textual criticism. Bijdragen tot de Taal-, Land- en Volkenkunde 137: 229-43.

Lauret, M. 2014. Wanderwords: language migration in American literature. London/New York: Bloomsbury.

Mason, P. 2016. Fight-dancing and the festival: Tabuik in Pariaman, Indonesia and Iemanjá in Salvador da Bahia, Brazil. Martial Arts Studies 2: 71-90.

McCallum, J. 2017a. Beguiling voices: traces of vocality in the Malay literary tradition of the Riau islands. Ethnomusicology Forum 1: 93-115.

McCallum, J. 2017b. Conflict and compromise over processional sound in nineteenth-century Singapore. Indonesia and the Malay World 45 (133): XXX-XXX.

McGlynn, J.H. and Suryadi. 2014. Introduction. In Muhammad Saleh, Krakatau: the tale of Lampung submerged. Translated by John H. McGlynn. Jakarta: Lontar Foundation. pp. vi-xxxi.

Milner, A. 2002. The invention of politics in colonial Malaya. Cambridge: Cambridge University Press. First edition 1995.

Murtagh, B. 2002. Syair Perang Inggeris Di Betawi: a Malay account of the British invasion of Java of 1811. Indonesia and the Malay World 30 (86): 27-36.

Newell, S. 2001. 'Paracolonial' networks: some speculations on local readerships in colonial west Africa. Interventions: international journal of postcolonial studies 3 (3): 336-54.

Pearson, H.F. 1953. Lt. Jackson's Plan of Singapore. Journal of the Malayan Branch of the Royal Asiatic Society 26 (1): 200-4.

Pieris, A. 2009. Hidden hands and divided landscapes: a penal history of Singapore's plural society. Honolulu: University of Hawai‘i Press.

Platts, J.T. 1884. A dictionary of Urdu, classical Hindi, and English. London: W.H. Allen \& Co.

Proudfoot, I. 1987. A nineteenth-century Malay bookseller’s catalogue. Kekal Abadi 6 (4): 111.

Proudfoot, I. 1993. Early Malay printed books. Kuala Lumpur: University of Malaysia.

Proudfoot, I. 1995. Early Muslim printing in Southeast Asia. Libri 45: 216-23.

Proudfoot, I. 1998. Lithography at the crossroads of the East. Journal of the Printing Historical Society 27: 113-31.

Proudfoot, I. 2002. From recital to sight singing: the silencing of texts in Malaysia, Indonesia and the Malay World. Indonesian and the Malay World 30 (87): 117-44.

Proudfoot, I. and Hooker, V. 1996. Mediating time and space: the Malay writing tradition. In Ann Kumar and John McGlynn (eds), Illuminations: the writing traditions of Indonesia. New York: Weatherhill, pp. 49-78.

Putten, J. van der. 2013. Woe from wit: burlesquing Muharram processions into carnivalesque boria. In Jelani Harun and Ben Murtagh (eds), Esei penghargaan kepada profesor Emeritus V. I. Braginsky: mengharungi laut sastera Melayu/Festschrift in honour of Professor Emeritus V. I. Braginsky: crossing the sea of Malay literature. Kuala Lumpur: Dewan Bahasa dan Pustaka, pp. 569-602. 
This is the accepted version of a forthcoming article that will be published by Taylor \& Francis in Indonesia and the Malay World: http://www.tandfonline.com/loi/cimw20

Accepted version downloaded from SOAS Research Online: http://eprints.soas.ac.uk/24486/

Putten, J. van der. 2015. Burlesquing Muharram processions into carnivalesque boria. In Chiara Formichi and R. Michael Feener (eds), Shi 'ism in Southeast Asia: 'Alid piety and sectarian constructions. London: Hurst, pp. 203-22.

Rai, R. 2013. The 1857 panic and the fabrication of an Indian 'menace' in Singapore. Modern Asian Studies 47 (2): 365-405.

Rai, R. 2014. Indians in Singapore, 1819-1945: diaspora in the colonial port city. New Delhi: Oxford University Press.

Raja Iskandar bin Raja Halid. 2015. The Malay nobat: a history of encounters, accommodation and development. PhD dissertation, King's College London.

Read, W.H.M. 1901. Play and politics: recollections of Malaya by an old resident. London: Wells Gardner, Darton \& Co.

Savage, V.R. and Yeoh, B.S.A. 2013. Singapore street names: a study of toponymics. Singapore: Marshall Cavendish.

Schofield, K.B. 2016. Musical transitions to European colonialism in the eastern Indian Ocean: Final activity report. European Research Council. Available at http://cordis.europa.eu

Sharif, Ja'far. 1975. Islam in India, or the Qānūn-i-Islām. Tr. G. A. Herklots. Revised edition William Crooke. London: Curzon Press. Original edition 1832.

Steingass, F. 1963 [1892]. A comprehensive Persian-English dictionary. 5th impression. London: Routledge and Kegan Paul.

Stevens, A.M. and Schmidgall-Tellings, A. 2010. A comprehensive Indonesian-English dictionary. 2nd edn. Athens OH: Ohio University Press.

Sweeney, A. 2006. Karya Lengkap Abdullah bin Abdul Kadir Munsyi, Jilid 2: puisi dan ceretera [Complete works of Abdullah bin Abdul Kadir Munsyi, vol. 2: poetry and stories]. Jakarta: Kepustakaan Populer Gramedia/École française d’Extrême-Orient.

Sykes, J. 2015. Towards a Malayan Indian sonic geography: sound and social relations in colonial Singapore. Journal of Southeast Asian Studies 46 (3): 485-513.

Tschacher, T. 2009. Circulating Islam: understanding convergence and divergence in the Islamic traditions of Ma'bar and Nusantara. In R. Michael Feener and Terenjit Sevea (eds), Islamic connections: Muslim societies in South and Southeast Asia. Singapore: ISEAS, pp. 48-67.

Tschacher, T. 2010. Witnessing fun: Tamil-speaking Muslims and the imagination of ritual in colonial Southeast Asia. In Michael Bergunder, Heiko Frese and Ulrike Schröder (eds), Ritual, caste, and religion in colonial South Asia. Halle: Franckesche Siftungen, 2010, pp. 189-218.

Turnbull, C.M. 1972. The Straits Settlements, 1826-67: Indian Presidency to Crown colony. London: Athlone Press.

Turnbull, C.M. 2009. British colonialism and the making of the modern Johor monarchy. Indonesia and the Malay World 37 (109): 227-48.

Ward, J.S.M. and Stirling, W.G. 1925. The Hung society, or the society of heaven and earth. Vol. 1. London: Baskerville Press.

Welch, S.C. 1978. Room for wonder: Indian painting during the British period 1760-1880. New York: American Federation of Arts/Rizzoli.

Wilkinson, R.J. 1903. A Malay-English Dictionary. Singapore: Kelly and Walsh.

Wilkinson, R.J. 1907. Malay literature: romance, history, poetry. Papers on Malay subjects: Malay literature. Part 1. Kuala Lumpur: Federated Malay States Government Press.

Wynne, M.L. 1941. Triad and Tabut: a survey of the origin and diffusion of Chinese and Mohamedan secret societies in the Malay peninsula, A.D. 1800-1935. Singapore: Government Printing Office. 